\title{
Lithostratigraphy and lithogeochemistry of Ediacaran alkaline basaltic rocks of the Musgravetown Group, Bonavista Peninsula, northeastern Newfoundland, Canada: an extensional volcanogenic basin in the type-Avalon terrane
}

\author{
Andrea Mills ${ }^{*}$ and Hamish Sandeman \\ Geological Survey of Newfoundland and Labrador, Department of Industry, Energy and Technology, \\ St. John's, Newfoundland and Labrador A1B 4J6, Canada \\ ${ }^{*}$ Corresponding author <andreamills@gov.nl.ca>
}

Date received: 22 April 2021 Date accepted: 20 June 2021

\begin{abstract}
Volcanic rocks of the Ediacaran Musgravetown Group on Bonavista Peninsula, Avalon terrane, Newfoundland, include basal ca. $600 \mathrm{Ma}$ calc-alkaline basalt succeeded by continental tholeiite and alkaline rhyolite of the ca. 592 Ma Plate Cove volcanic belt (Bull Arm Formation), indicating a change from subduction-related to extensionrelated tectonic regimes during that interval. Alkalic basalts on northeastern (Dam Pond area) and southwestern (British Harbour area) Bonavista Peninsula occur below and above, respectively, the ca. 580 Ma glacial Trinity facies. Dam Pond basalt occurs in a structural dome intercalated with and flanked by fine-grained, siliciclastic deposits (Big Head Formation) overlain by Trinity facies. The British Harbour basalt occurs above the Trinity facies, in an upward-coarsening sandstone sequence (Rocky Harbour Formation) overlain by red beds of the Crown Hill Formation (uppermost Musgravetown Group). The Rocky Harbour and Big Head formations are likely stratigraphically interfingered proximal and distal deposits, respectively, derived from erosion of the Bull Arm Formation and older Avalonian assemblages.

The Big Head basalts have lower $\mathrm{SiO}_{2}, \mathrm{Zr}, \mathrm{FeO}^{\mathrm{T}}, \mathrm{P}_{2} \mathrm{O}_{5}, \mathrm{TiO}_{2}$ and higher $\mathrm{Mg} \#, \mathrm{Cr}, \mathrm{V}$, Co and Ni contents, and are therefore more primitive than the more $\mathrm{FeO}^{\mathrm{T}}$-, $\mathrm{TiO}_{2}$, and $\mathrm{P}_{2} \mathrm{O}_{5}$-rich British Harbour basalts. Large-ionlithophile and rare-earth-element concentrations and ratios indicate that both suites originated from low degree partial melts of deep, weakly garnet-bearing, undepleted asthenospheric peridotite sources, with magma conduits likely focused along regional extensional faults. The protracted and episodic extension-related volcanic activity is consistent with a geodynamic setting that evolved from a mature arc into extensional basins with slowly waning magmatism, possibly involving slab rollback and delamination followed by magmatic underplating. The duration and variation of both volcanism and sedimentation indicate that the Musgravetown Group should be elevated to a Supergroup in order to facilitate future correlation of its constituent parts with other Avalonian basins.
\end{abstract}

\section{RÉSUMÉ}

Les roches volcaniques du groupe d'Ediacara de Musgravetown sur la péninsule de Bonavista, terrane d'Avalon, à Terre-Neuve, comprennent des basaltes calcoalcalins basaux d'environ $600 \mathrm{Ma}$ auxquels ont succédé de la tholéiite continentale et de la rhyolite alcaline de la ceinture volcanique d'environ $592 \mathrm{Ma}$ de Plate Cove (Formation de Bull Arm), ce qui révèle un passage d'un régime tectonique de subduction à un régime d'extension durant cet intervalle. Les basaltes alcalins dans le nord-est (secteur de Dam Pond) et le sud-ouest (secteur de British Harbour) de la péninsule de Bonavista se manifestent au-dessous et au-dessus, respectivement, du faciès glaciaire d'environ 580 Ma de Trinity. Le basalte de Dam Pond apparaît dans un dôme interstratifié et flanqué de dépôts silicoclastiques à grains fins (Formation de Big Head) recouverts du faciès de Trinity. Les basaltes de British Harbour se trouvent au-dessus du faciès de Trinity, dans une séquence de grès à granulométrie croissante vers le haut (Formation de Rocky Harbour) recouverte de couches rouges de la Formation de Crown Hill (partie sommitale du groupe de Musgravetown). Les Formations de Rocky Harbour et de Big Head sont vraisemblablement stratigraphiquement interdigitées de dépôts proximaux et distaux, respectivement, provenant de lérosion de la Formation de Bull Arm et d'assemblages avaloniens plus anciens.

Les basaltes de $\mathrm{Big}$ Head ont des teneurs inférieures de $\mathrm{SiO}_{2}$, de $\mathrm{Zr}$, de $\mathrm{FeO}^{\mathrm{T}}$, de $\mathrm{P}_{2} \mathrm{O}_{5}$ et de $\mathrm{TiO}_{2}$, et des teneurs supérieures de $\mathrm{Mg} \#$, de $\mathrm{Cr}$, de $\mathrm{V}$, de Co et de $\mathrm{Ni}$; ils sont en conséquence plus primitifs que les basaltes plus riches 
en $\mathrm{FeO}^{\mathrm{T}}$, en $\mathrm{TiO}_{2}$ et en $\mathrm{P}_{2} \mathrm{O}_{5}$ de British Harbour. Les ratios et les concentrations d'éléments lithophiles à grand rayon ionique et de métaux des terres rares signalent que les deux suites proviennent de fontes partielles de faible degré de sources de péridotite asthénosphérique non appauvrie, faiblement grenatifère, profondes, avec des conduits magmatiques probablement concentrés le long de failles d'extension régionales. L'activité volcanique apparentée à l'extension, prolongée et épisodique, correspond à un milieu géodynamique ayant évolué d'un arc à maturité en bassins d'extension au magmatisme s'affaiblissant lentement, comportant possiblement un repositionnement de dalles et une délamination suivis d'un sous-placage magmatique. La durée et la variation du volcanisme et de la sédimentation révèlent que le groupe de Musgravetown devrait être reclassé en un supergroupe pour faciliter la corrélation future de ses composantes avec d'autres bassins avaloniens.

[Traduit par la redaction]

\section{INTRODUCTION}

The Musgravetown Group (Hayes 1948) includes a thick succession of mainly coarse clastic sedimentary and interbedded volcanic rocks that unconformably overlie the turbidite-dominated Connecting Point Group (Hayes 1948) and are unconformably to disconformably overlain by quartz arenite of the marine-platformal, lower Cambrian Random Formation (Walcott 1900; Anderson 1981; Hiscott 1982; Fig. 1). On Bonavista Peninsula, the Musgravetown Group (as per Jenness 1963) comprises (1) the basal, dominantly conglomeratic Cannings Cove Formation, overlain in turn by (2) the mainly volcanic Bull Arm Formation, (3) undifferentiated middle formation(s) comprising red and green-grey sandstone, siltstone, and conglomerate, (4) immature, cross-stratified sandstone of the Rocky Harbour Formation, and (5) chiefly red-pebble conglomerate and sandstone of the Crown Hill Formation (Fig. 2; Table 1). Normore (2010) assigned an extensive grey-green siltstone unit on eastern Bonavista Peninsula (Fig. 3) to the Big Head Formation (McCartney 1967), named for the unvegetated hilltop in the Long Harbour area (Fig. 1). On Bonavista Peninsula, the Big Head Formation lies above the Bull Arm Formation and was interpreted by Normore (2010) to be unconformably onlapped by the Rocky Harbour Formation, conceivably within the stratigraphic position of Jenness' (1963) undifferentiated middle formation(s) (Fig. 2). The aerial extent of the Musgravetown Group is vast: it underlies much of the Bay de Verde and Cape St. Mary's sub-peninsulas of the western Avalon Peninsula and much of the northwestern Avalon terrane where alternating volcanic and sedimentary rock-dominated, north- to north-northeast-trending belts of Musgravetown Group are separated by a southward-narrowing corridor underlain by Connecting Point Group (King 1988; O’Brien et al. 1996; Mills et al. 2020; Fig. 1).

On the Bonavista Peninsula, earliest magmatism involved the calc-alkaline Headland basalt (Mills and Sandeman 2015; see Fig. 3), which is interbedded with coarse conglomeratic rocks of the Cannings Cove Formation (basal Musgravetown Group). The Cannings Cove Formation, locally dated at ca. $600 \mathrm{Ma}$ (Mills et al. 2016b), marks an abrupt switch from dominantly turbiditic rocks and tuffs of the upper Connecting Point Group to coarse-clastic sedimentation at the base of the Musgravetown Group. By ca.
$592 \mathrm{Ma}$ (Mills et al. 2017), the dominant magmatic products are transitional (weakly calc-alkaline to tholeiitic) basalts (Mills and Sandeman 2015) and weakly alkaline felsic volcanic rocks (Mills 2020), which, along with tuffaceous and epiclastic rocks, comprise the Plate Cove volcanic belt (Figs. 2 and 3). Considered part of the Bull Arm Formation, the chemistry of these volcanic rocks indicates a significant change from the earlier suprasubduction zone, calc-alkaline Cannings Cove basalts to younger (Bull Arm Formation) continental tholeiite produced by the upwelling of partial melts generated from a relatively shallow, enriched midocean ridge basalt (EMORB)-like source (Mills and Sandeman 2015) having Sm-Nd model ages of 700-900 Ma (Mills et al. 2020; Mills, unpublished data). In contrast, the Dam Pond basalts of the northeastern Bonavista Peninsula, first documented by Normore (2010), are alkalic basalts derived by low degree partial melting of a deep $(\sim 60-90 \mathrm{~km}$; Mills and Sandeman 2015; see also Pearce 2008), enriched mantle source. Normore (2010) assigned the Dam Pond basalts to the Bull Arm Formation, but lithogeochemical and lithostratigraphic differences between the Dam Pond and Plate Cove volcanic belt basalts make this correlation unlikely (Mills and Sandeman 2015).

This contribution builds on previous investigations of volcanic rocks of the Bonavista Peninsula (Mills and Sandeman 2015, 2017), adding new observations and lithogeochemical data for basalts, first reported by Normore (2012a, b), on the island of Ireland's Eye and northeastern Random Island, Trinity Bay, and extending intermittently northward to $5 \mathrm{~km}$ north of British Harbour (Figs. 3-4). Field relationships, petrographic descriptions and the lithogeochemical character of these rocks are summarized herein, and revised lithostratigraphic designations are proposed (Table 1). The data also help to better constrain the nature of magmatism and tectonic evolution in terms of the timing of multiple pulses of major crustal extension in the Avalon terrane of Newfoundland.

\section{REGIONAL GEOLOGY}

Previous workers (e.g., Hayes 1948; Christie 1950; Jenness 1963) assigned nearly all rocks on the Bonavista Peninsula to the Musgravetown Group. The succession exposed east of the Spillars Cove fault zone (SPFZ; O'Brien and King 


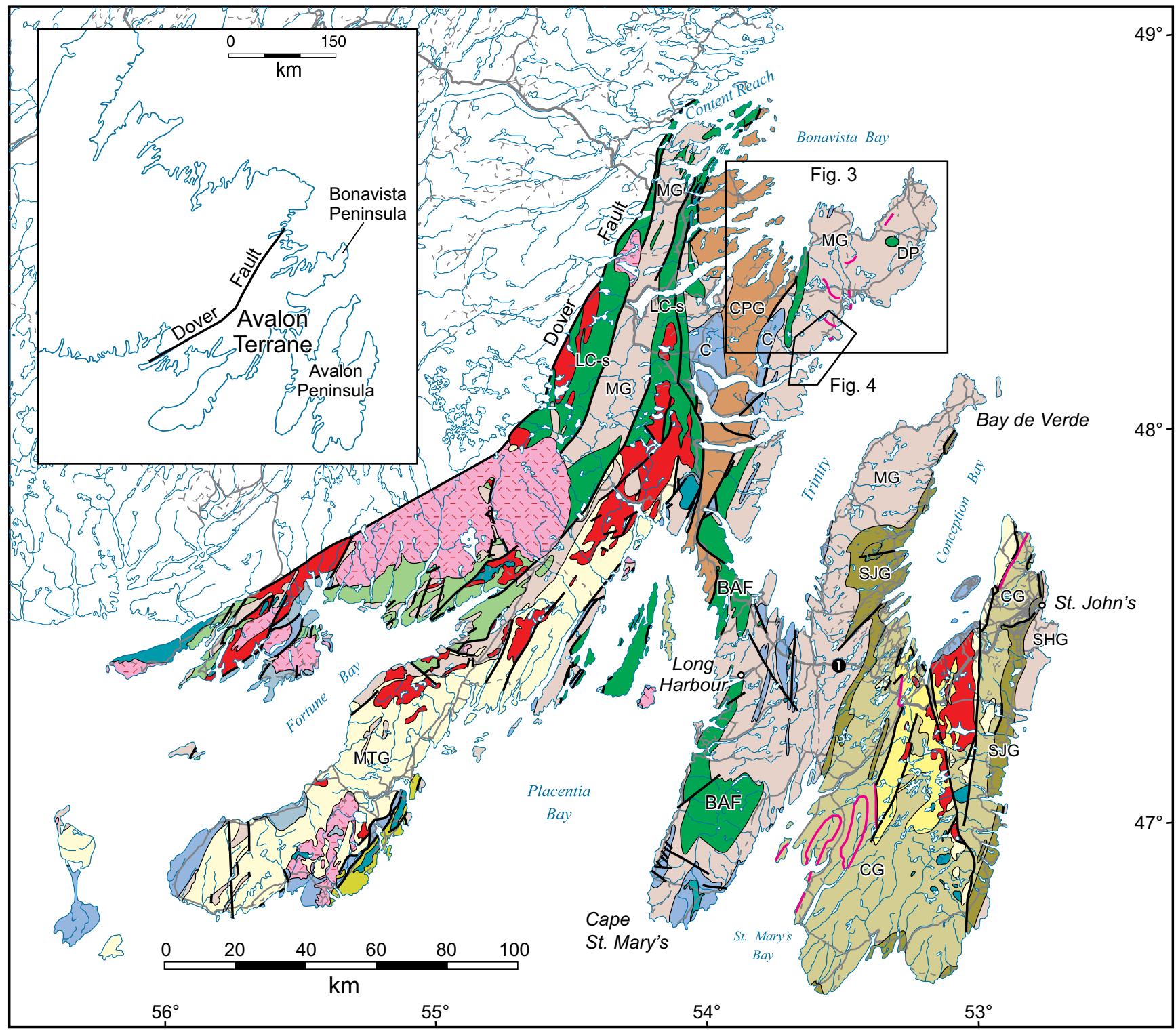

\section{AVALON TERRANE}
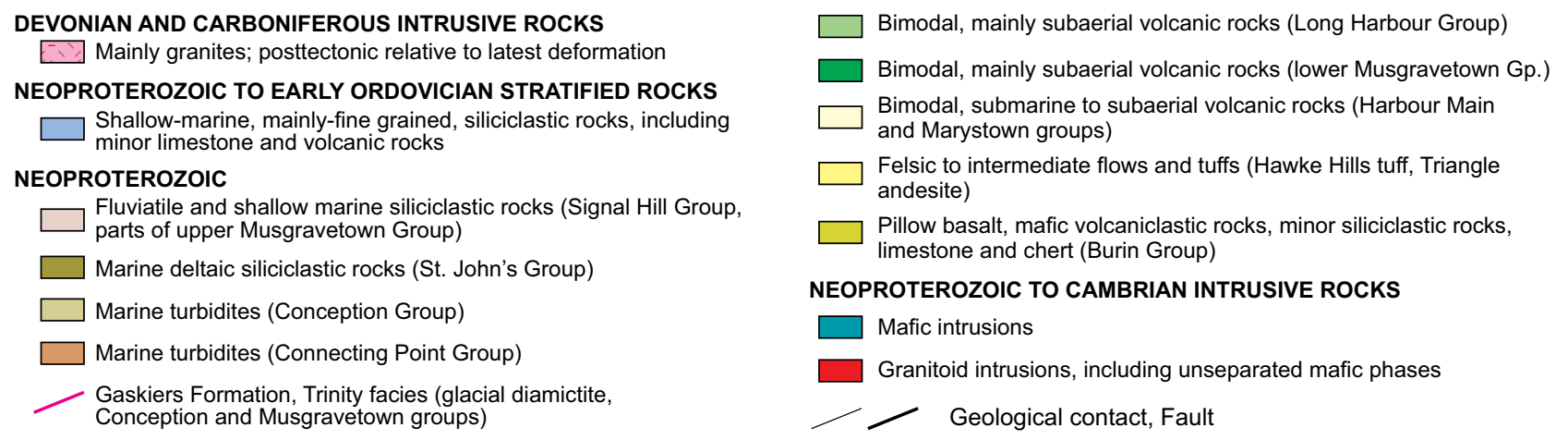

Figure 1. Simplified geological map of the Avalon terrane in Newfoundland (modified from Colman-Sadd et al. 1990). $\mathrm{BAF}=$ Bull Arm Formation; $\mathrm{C}=$ Cambrian rocks; $\mathrm{CG}=$ Conception Group; $\mathrm{CPG}=$ Connecting Point Group; $\mathrm{DP}=\mathrm{Dam}$ Pond basalts; MG = Musgravetown Group; MTG - Marystown Group; LC-s = Love Cove schist (tectonized pyroclastic rocks correlative with Bull Arm Formation); SHG = Signal Hill Group; STJ = St. John's Group. 
(a) Southwestern Bonavista Peninsula

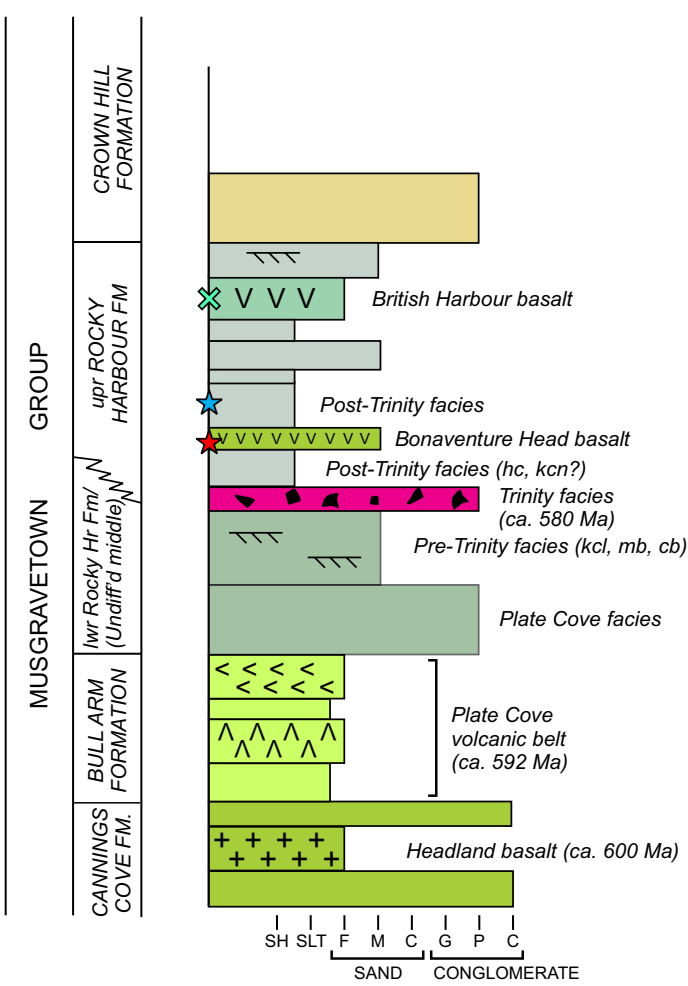

(b) Northeastern Bonavista Peninsula

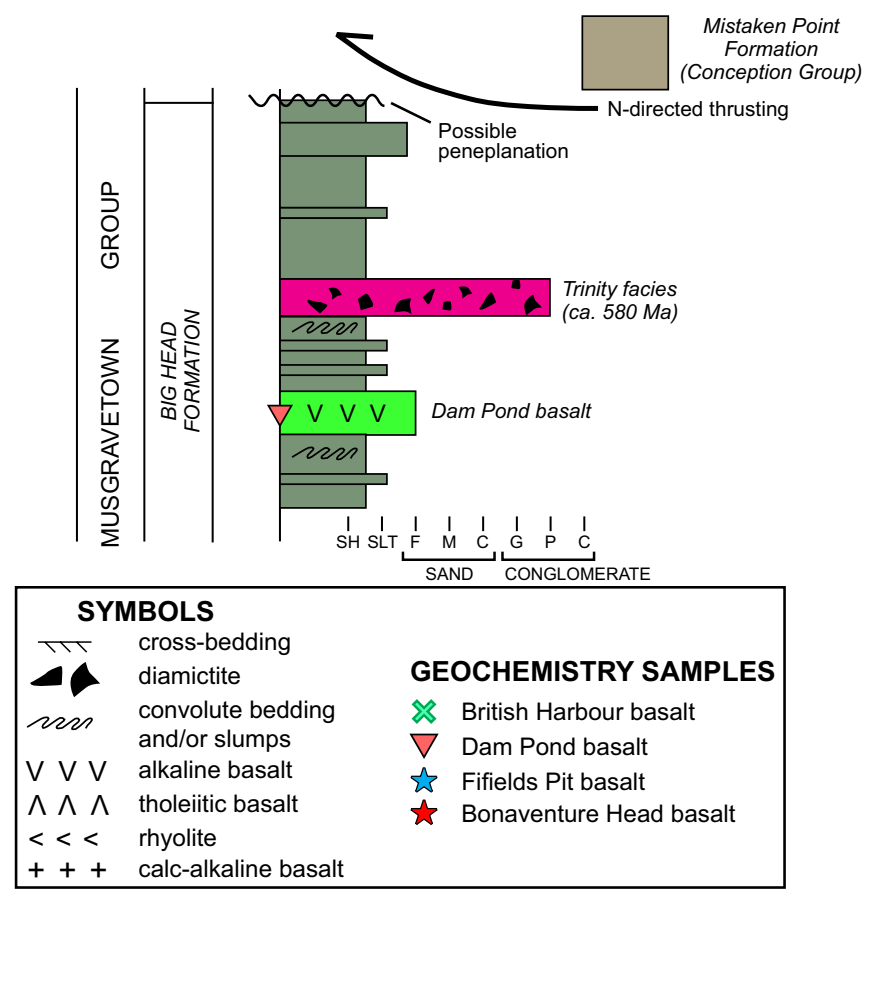

Figure 2. Schematic stratigraphic sections for (a) southwestern and (b) northeastern parts of the Bonavista Peninsula showing the relative positions and names of units discussed in the text. Age constraints are from Mills et al. (2017) and Pu et al. (2016). The estimated thickness of the Trinity facies is approximately $50 \mathrm{~m}$.

2004; Fig. 3), however, contains Ediacaran fauna in rocks forming an antiformal dome near Catalina, thereby leading to correlation of this succession with parts of the Conception, St. John's and Signal Hill groups of the eastern Avalon Peninsula (O'Brien and King 2002, 2004, 2005; Hofmann et al. 2008; Normore 2010, 2011; Mason et al. 2013). Most of the rocks west of the SCFZ were assigned to the Rocky Harbour Formation (O'Brien and King 2005) based on their stratigraphic position above the volcanic Bull Arm Formation (Plate Cove volcanic belt of Mills and Sandeman 2015) and below red beds of the Crown Hill Formation. However, several lithostratigraphic subdivisions of the Rocky Harbour Formation have been proposed (see below), but conflicting accounts of the order and number of proposed units are confusing and demand revision (Table 1). The broadest subdivision recognizes a coarse clastic-dominated unit to the west and a fine-grained, siliceous unit to the east (Fig. 2) (O'Brien and King 2002, 2004, 2005; Normore 2010, 2011). Whereas O'Brien and King (2005) assigned the eastern, fine-grained unit to their Wilson's Pond facies, Normore $(2010,2011)$ placed these rocks in the Big Head Formation (cf. McCartney 1967), and both O'Brien and King (2005) and Normore $(2010,2011)$ proposed that this unit lies stratigraphically below a complex series of interfingered 'facies' comprising the Rocky Harbour Formation to the west. Normore's $(2010,2011)$ Big Head Formation is used here rather than O'Brien and King's (2005) 'Wilson Pond facies', as the broader subdivision of the former distinguishes it from the mainly coarse clastic units of the Rocky Harbour Formation and better allows for eventual correlation between it and the Rocky Harbour Formation. Here, the Big Head Formation is considered a coeval, more distally deposited lateral equivalent of the mainly coarse-grained clastic facies of the Rocky Harbour Formation. Previously proposed lithostratigraphic subdivision of the Rocky Harbour Formation (into as many as seven units or 'facies'; O'Brien and King 2002, 2004, 2005; Normore 2010, 2011; Table 1) recognize complex lateral and vertical variations in lithofacies, some of which may be only locally developed and therefore of limited use for regional mapping.

Perhaps the most regionally significant siliciclastic map unit of the Musgravetown Group is the glacial diamictite known as the Trinity facies (Normore 2011; Pu et al. 2016). This critical marker horizon is recognized within both the Rocky Harbour and Big Head formations on Bonavista Peninsula (Normore 2011; mixtite unit of Normore 2010; see Figs. 2-3) and in the Long Harbour area, $120 \mathrm{~km}$ to the south (Fig. 1; Brückner 1977; see also Mills and Sandeman 2021). The Trinity facies includes variably coloured, purple or maroon to red, and grey to grey-green, massive, clast-poor to clast-rich diamictite with mixed mud and sand matrix, and finely laminated, dropstone-bearing, matrix-supported, muddy diamictite. Evidence of its glacial origin includes striations and faceted textures on clasts and the deformation 


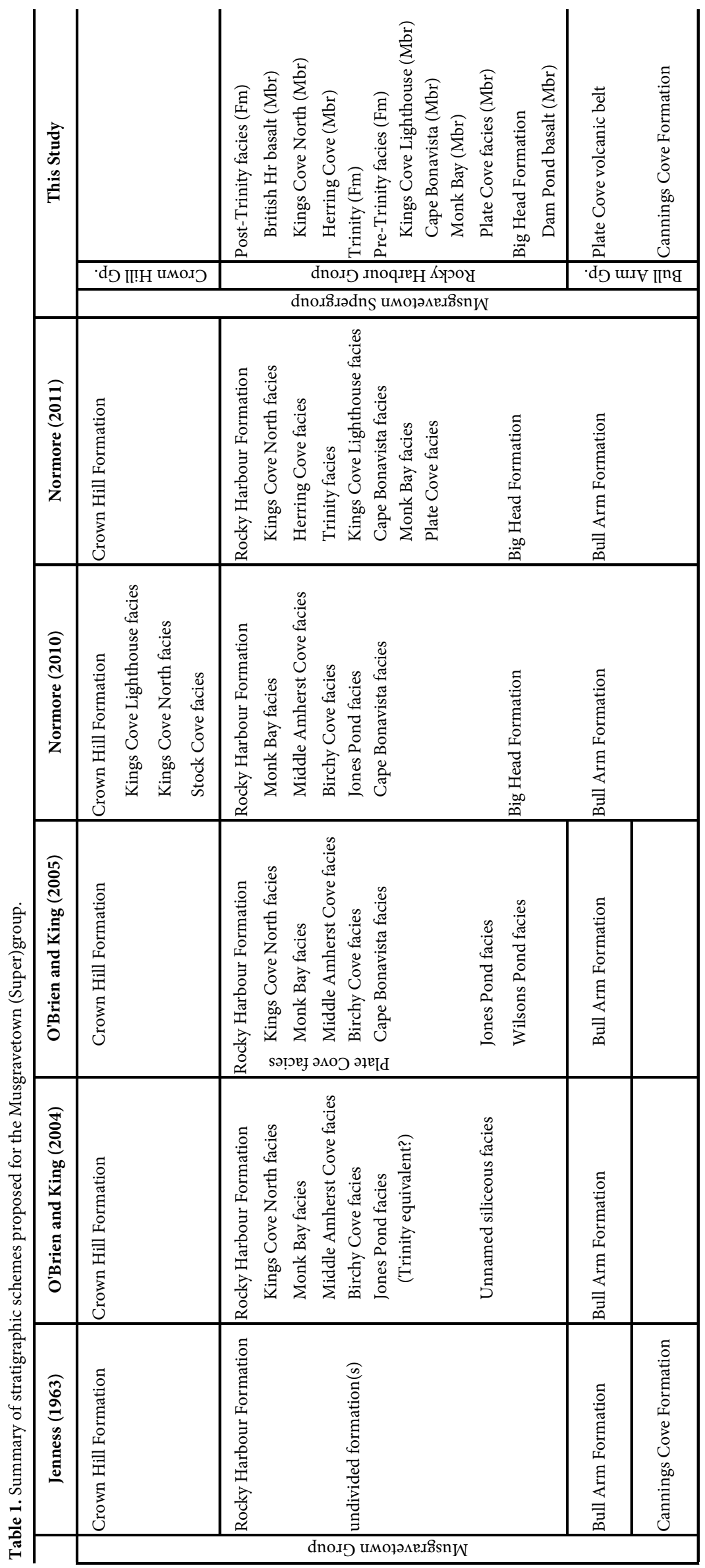




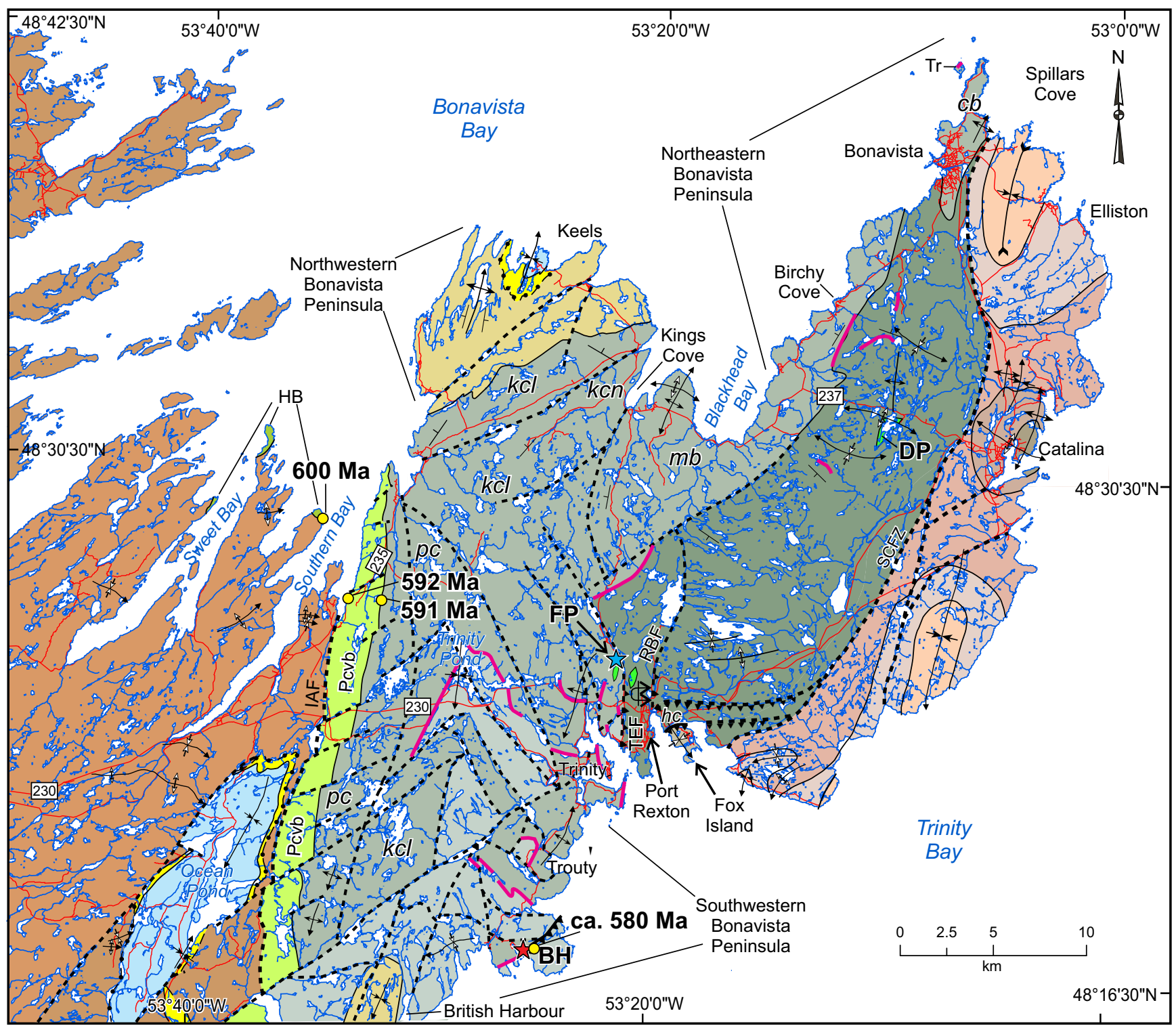

\section{LEGEND}

WEST BONAVISTA

Cambrian

$\square$ Adeyton Group

$\square$ Random Formation Ediacaran

Musgravetown Group

$\square$ Canning Cove Formation

Connecting Point Group

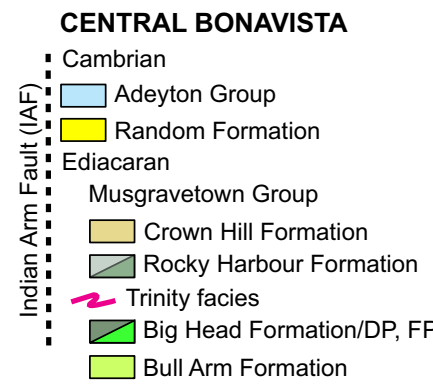

\section{EAST BONAVISTA}

Ediacaran

St. John's Group

Renews Head Formation

Fermeuse Formation

S $\square$ Trepassey Formation

Conception Group

Mistaken Point Formation

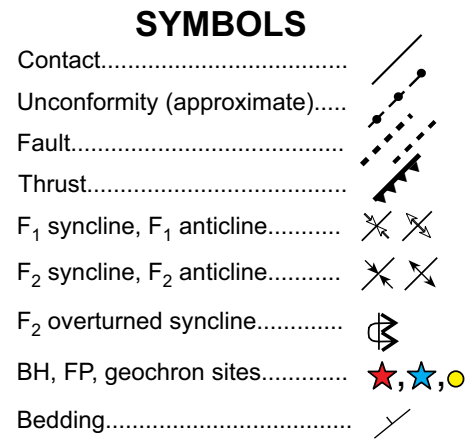

Figure 3. Simplified geology of the Bonavista Peninsula (modified from O'Brien and King 2005) showing the location of Fifields Pit (FP) basalt and Bonaventure Head (BH) basalt. $\mathrm{HB}=$ Headland basalts; $\mathrm{DP}=\mathrm{Dam}$ Pond basalt; PCvb = Plate Cove volcanic belt (Bull Arm Formation); SCFZ = Spillars Cove fault zone; RBF = Robinhood Bay fault; TEF = Trinity East fault; IAF = Indian Arm fault. Units/facies of the Rocky Harbour Formation referred to in the text: pc $=$ Plate Cove; $\mathrm{kcl}=$ Kings Cove Lighthouse; $\mathrm{kcn}=$ Kings Cove North; $\mathrm{mb}$ - Monk Bay; $\mathrm{cb}=$ Cape Bonavista; hc = Herring Cove (see O'Brien and King 2002, 2004, 2005; Normore 2010, 2011; Table 1). 


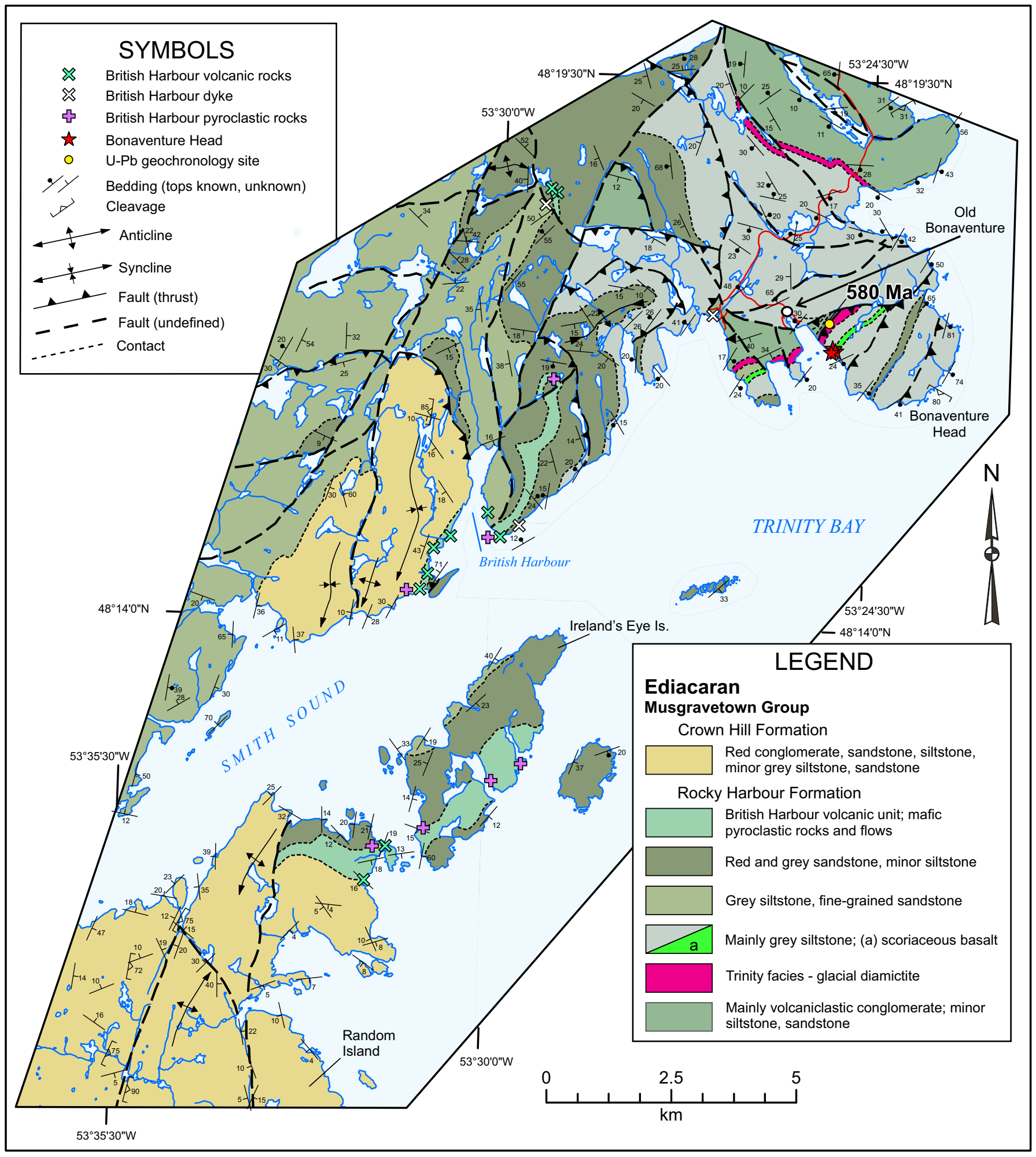

Figure 4. Preliminary map of Bonaventure - British Harbour - Ireland's Eye area, showing the locations of British Harbour and Bonaventure Head basalt samples, and highlighting the Trinity facies marker horizon.

of laminae underlying many clasts (Normore 2011). On the southern Bonavista Peninsula, the Trinity facies averages $40-50 \mathrm{~m}$ in thickness, and has been chronostratigraphically correlated with the 250- to 300-m thick diamictite sequence of the Gaskiers Formation of the Conception Group on
Avalon Peninsula (Fig. 1), based on U-Pb (zircon) CA ID TIMS geochronology of underlying and overlying tuffs near Old Bonaventure (Fig. 4) (Pu et al. 2016; Fig. 1). These tuff horizons yielded $\mathrm{U}-\mathrm{Pb}$ (zircon) ages of $579.63 \pm 0.15 \mathrm{Ma}$ and $579.24 \pm 0.17 \mathrm{Ma}$, respectively (Pu et al. 2016). 
The tracing of the Trinity facies diamictite on the Bonavista Peninsula has proved problematic and hence its distribution and deformation-controlled geometry remain poorly understood. Its most northerly exposure is on the northern tip of Green Island, $\sim 1 \mathrm{~km}$ west of Cape Bonavista (Fig. 3). The Trinity facies is exposed on a ridge $\sim 2 \mathrm{~km}$ east of Birchy Cove, and O'Brien and King (2005) described lithologically similar rocks (their Jones Pond facies; see Table 1) south of the community of Bonavista. Normore (2010) indicated further exposures northwest and southwest of Dam Pond (see Fig. 3). Many of these exposures occur within Normore's $(2010,2011)$ Big Head Formation. On the southwestern part of the peninsula, Normore (2011) identified several occurrences of the Trinity facies. The lithostratigraphic complexity that Normore (2011) conveys (see fig. 4 in Normore 2011) is likely due, in part, to the discontinuous nature of complex lithofacies deposited in peri-glacial settings across an extremely rugged paleotopography (Brückner and Anderson 1971; Hughes and Brückner 1971; Gardiner and Hiscott 1988). Because the Trinity facies occurs in both the Rocky Harbour and Big Head formations, the onlap of the latter formation by the former must include extensive stratigraphic interfingering of lithofacies (Fig. 2).

\section{LITHOSTRATIGRAPHIC AND STRUCTURAL COMPLEXITIES OF THE BIG HEAD AND ROCKY HARBOUR FORMATIONS}

\author{
Pre-Trinity facies units (591-580 Ma)
}

Tholeiitic basalt, weakly alkaline felsic flows, pyroclastic deposits, and lesser sedimentary rocks comprise the ca. 592 Ma Plate Cove volcanic belt (Bull Arm Formation), which is "basement" to the overlying, dominantly shallow-marine Rocky Harbour Formation on Bonavista Peninsula. The conglomeratic Plate Cove facies (O’Brien and King 2005), a coarse clastic unit that stratigraphically overlies and crops out east of the Plate Cove volcanic belt, is overlain to the north and east by the Kings Cove Lighthouse facies and the Monk Bay facies, respectively (Normore 2010, 2011; see Fig. 3 and Table 1). The Kings Cove Lighthouse facies includes cross-bedded sandstone, thin conglomeratic layers and lenses, and maroon to purple mud drapes. The Monk Bay facies includes similar lithologies, but the mud drapes are grey-green, and thick $(>1 \mathrm{~m})$ green mudstone layers and mega-ripples are common (Normore 2010, 2011). Local large-scale epsilon cross-bedding in Kings Cove Lighthouse facies rocks south of Kings Cove was interpreted to reflect a Gilbert-type (fluvial-dominated) deltaic setting (Normore 2010), whereas symmetric mega-ripples characteristic of the Monk Bay facies were interpreted to reflect a shoreline or shallow marine setting (Normore 2010). The salient point here is that although these facies indicate distinctive depositional environments, they may well be coeval. Normore (2011) proposed that cross-bedded, medium- to coarsegrained sandstone of the Cape Bonavista facies interfingers with rocks of the Monk Bay facies, and is transitional into Kings Cove Lighthouse facies. Each of these facies was suggested as a potential map unit, but lateral and vertical facies changes and interdigitation limit regional extrapolation as separate, distinct units. The Plate Cove, King's Cove Lighthouse, Monk Bay, and Cape Bonavista facies (Figs. 2-3; Table 1) reflect differences in depositional settings (Normore 2010, 2011), and are all considered pre-glacial with respect to the Trinity facies (Normore 2011; Pu et al. 2016; this study; see Table 1). Diamictite of the Trinity facies is presumed to comprise a synchronous marker unit.

\section{Post-'Trinity facies' units $(<580 \mathrm{Ma})$}

The Trinity facies in the southwestern Bonavista Peninsula is typically overlain by $40-50 \mathrm{~m}$ of green-grey to bluegrey, finely laminated siltstone, fine-grained sandstone and minor conglomeratic lenses. These rocks are similar to the Kings Cove North facies of the upper Rocky Harbour Formation (Normore 2010, 2011) on northwestern Bonavista Peninsula (Fig. 3; Table 1). The Kings Cove North facies, at its type locality (see Fig. 3), was interpreted as flood plain or lacustrine deposits preserved as large-scale discontinuous lenses within coarse-grained, high-energy, meandering fluvial to deltaic strata of the Kings Cove Lighthouse facies (Normore 2010). Given that the Trinity facies overlies the Kings Cove Lighthouse facies on southwestern Bonavista Peninsula but is absent above the Kings Cove Lighthouse facies on northwestern Bonavista Peninsula (Fig. 3), it is possible that the lacustrine-like deposits of Kings Cove North facies (at its type locality on northwestern Bonavista Peninsula) may instead be glaciolacustrine in origin, and therefore chronostratigraphically equivalent to the Trinity facies. It is therefore proposed that peri-glacial depositional facies may be more widespread than currently recognized.

On southwestern Bonavista Peninsula, peach- to pistachio-coloured silicified tuffaceous beds intercalated with blue-grey siltstone above the Trinity facies are lithologically similar to interbedded siltstone and tuff of the Herring Cove facies (Normore 2011). At its type locality north of Fox Island (Fig. 3), the Herring Cove facies is structurally overlain to the south by rocks correlative with either the Mistaken Point Formation (upper Conception Group) or lower St. John's Group (Normore 2011; see Fig. 2b and Fig. 3). On southwestern Bonavista Peninsula, both the Kings Cove North and Herring Cove facies are considered post-glacial with respect to the Trinity facies (Normore 2011; Pu et al. 2016; this study).

\section{Structural and stratigraphic setting of the Dam Pond basalt}

The Dam Pond basalt on the northeastern Bonavista Peninsula crops out in a structural culmination and is overlain by siltstone and fine-grained sandstone of Normore's (2010, 2011) Big Head Formation (Figs. 2, 3). Trinity facies diamictite crops out to the north, northwest, and southwest, 
apparently stratigraphically above the Dam Pond basalt and overlying siltstone, indicating that the Dam Pond basalt is older than the Trinity facies. Bedding orientation reversals define east-west-trending $D_{1}$ folds that are nearly orthogonal to north-northeast-trending $\mathrm{D}_{2}$ faults, penetrative $S_{2}$ cleavage, and $F_{2}$ fold axes prevalent across the Bonavista Peninsula (Fig. 3). $\mathrm{D}_{1}$ deformation lacks penetrative cleavage on the Bonavista Peninsula and field evidence for $\mathrm{D}_{1}$ is best preserved as north-directed thrust faults and north-verging asymmetric folds reported on Fox Island (Fig. 3; Mills et al. 2016a). The age and magnitude of offset associated with both $\mathrm{D}_{1^{-}}$and $\mathrm{D}_{2}$-related faults have not been constrained but are younger than ca. $565 \mathrm{Ma}$, the inferred age of poly-deformed strata at both Catalina and Fox Island (Fig. 3; Mills et al. 2016a).

\section{Structural and stratigraphic setting of the British Harbour basalts}

The geology of the southwestern part of Bonavista Peninsula is complicated by polyphase deformation (Normore 2011; Mills et al. 2016a; see Figs. 3-4). West and south of Bonaventure Head, the strata coarsen upward above the Trinity facies from dominantly siltstone to coarse-grained sandstone, overlain by red beds of the Crown Hill Formation (Figs. 2-4). Between Bonaventure Head and British Harbour, the rocks young to the west, and basalt breccias and flows occur near the top of the dominantly grey, cross-stratified sandstone sequence. At Random and Ireland's Eye islands, the rocks young to the south, and basalt flows, agglomerate, and tuffaceous rocks overlie coarse-grained, grey sandstone and are overlain by red sandstone and conglomerate of the Crown Hill Formation (Figs. 2, 4) (Normore 2012a, b). The British Harbour volcanic and pyroclastic rocks are therefore considered to be younger than the ca. $580 \mathrm{Ma}$ Trinity facies.

\section{FIELD AND PETROGRAPHIC DESCRIPTIONS OF ALKALINE MAFIC VOLCANIC ROCKS, BONAVISTA PENINSULA}

\section{Dam Pond basalt}

The Dam Pond basalts are preserved in a structural culmination, likely produced by interference of $\mathrm{D}_{1}$ and $\mathrm{D}_{2}$ folds (Fig. 3), flanked by laminated to convoluted siltstone and lesser sandstone. Basaltic rocks at Dam Pond are dark- to light-green, vesicular to amygdaloidal, clinopyroxene-bearing flows and breccias (Normore 2010; Mills and Sandeman 2015) and are interbedded with thin-bedded grey siltstone. Diamictite overlies the siltstone $\sim 3.5 \mathrm{~km}$ to the southwest and about $5 \mathrm{~km}$ to the north and northwest (Fig. 3). The thickness of siltstone is indeterminable, due to bedding reversals, the confluence of brittle faults, and poor outcrop exposure.

The Dam Pond basalts contain relict, up to $2 \mathrm{~mm}$, subhedral clinopyroxene, which is commonly resorbed and variably altered to chlorite (see plates 3C-D of Mills and Sandeman 2015). Plagioclase exhibits a bimodal size distribution, with $\sim 1 \mathrm{~mm}$ phenocrysts and 100-200 $\mu \mathrm{m}$ laths in the groundmass. Amygdales average $2 \mathrm{~mm}$ in diameter and are filled by chlorite, carbonate, quartz, epidote, and adularia. Clasts in the basalt breccia include fine-grained, trachytic-textured basalt and highly vesicular, scoriaceous basalt. Skeletal plagioclase microcrysts and locally preserved chilled rims of some clasts indicate rapid quenching, possibly in a subaqueous setting. The matrix of most samples contains chlorite-altered patches associated with 30-50 $\mu \mathrm{m}$ titanite grains. The chlorite-titanite assemblage is unlikely to be magmatic, but a product of alteration that may be metamorphic, deuteric (i.e., due to late exsolved fluids related to eruption), or hydrothermal in origin.

\section{Fifields Pit basalt}

One sample of basaltic conglomerate from Fifields Pit, $3 \mathrm{~km}$ northwest of Port Rexton (Fig. 3), was collected for petrographic examination and lithogeochemical analysis. Detailed bedrock mapping undertaken by Cornerstone Resources in the early 2000s during exploration for Kupferschiefer-style copper mineralization identified two lenses of mafic volcanic breccia in the poorly exposed Fifields Pit area, north and west of Port Rexton (Graves 2003; Fig. 3). The elongate lenses, each about $1 \mathrm{~km}$ long by $200 \mathrm{~m}$ thick, occur within a subvertical to steeply east-dipping package of intercalated green and grey siltstone and sandstone, approximately $300 \mathrm{~m}$ and $1 \mathrm{~km}$ west of an overturned syncline (Graves 2003; Fig. 3). Several discrete north-trending faults are identified in the area (Normore 2011), but the entire subvertical rock package likely occurs within a complex fault zone (Fig. 3).

The Fifields Pit basalt comprises rounded basalt clasts, set in a vuggy to pink and white crystalline network (Fig. $5 a)$. The clasts exhibit textures ranging from scoriaceous to pilotaxitic to trachytic, and are surrounded by an interclast fill comprising mainly feldspar, epidote, and prehnite (Fig. $5 b)$. The latter phases are interpreted to have crystallized in interfragmental voids as a post-magmatic fluid percolated through the conglomeratic basalt. Some chlorite blebs may be pseudomorphs of precursor olivine. Clinopyroxene occurs both as phenocrysts (Fig. 5b) ranging up to $5 \mathrm{~mm}$ and also as microcrysts in some of the basaltic fragments. Rare hourglass zoning of some phenocrysts (Fig. 5c), feathery crystal habit, and swallowtail terminations of some microcrysts (Fig. 5d) are indicative of rapid clinopyroxene crystallization (Wass 1973), possibly in a subaqueous eruptive setting, consistent with the interpretation of the laminated to convolute siltstone interbedded with the basalt as subaqueous deposits.

\section{Bonaventure Head basalt}

At Bonaventure Head (Figs. 3-4), a 25 m-thick, clast-supported tuffaceous breccia (Fig. 6a) containing 

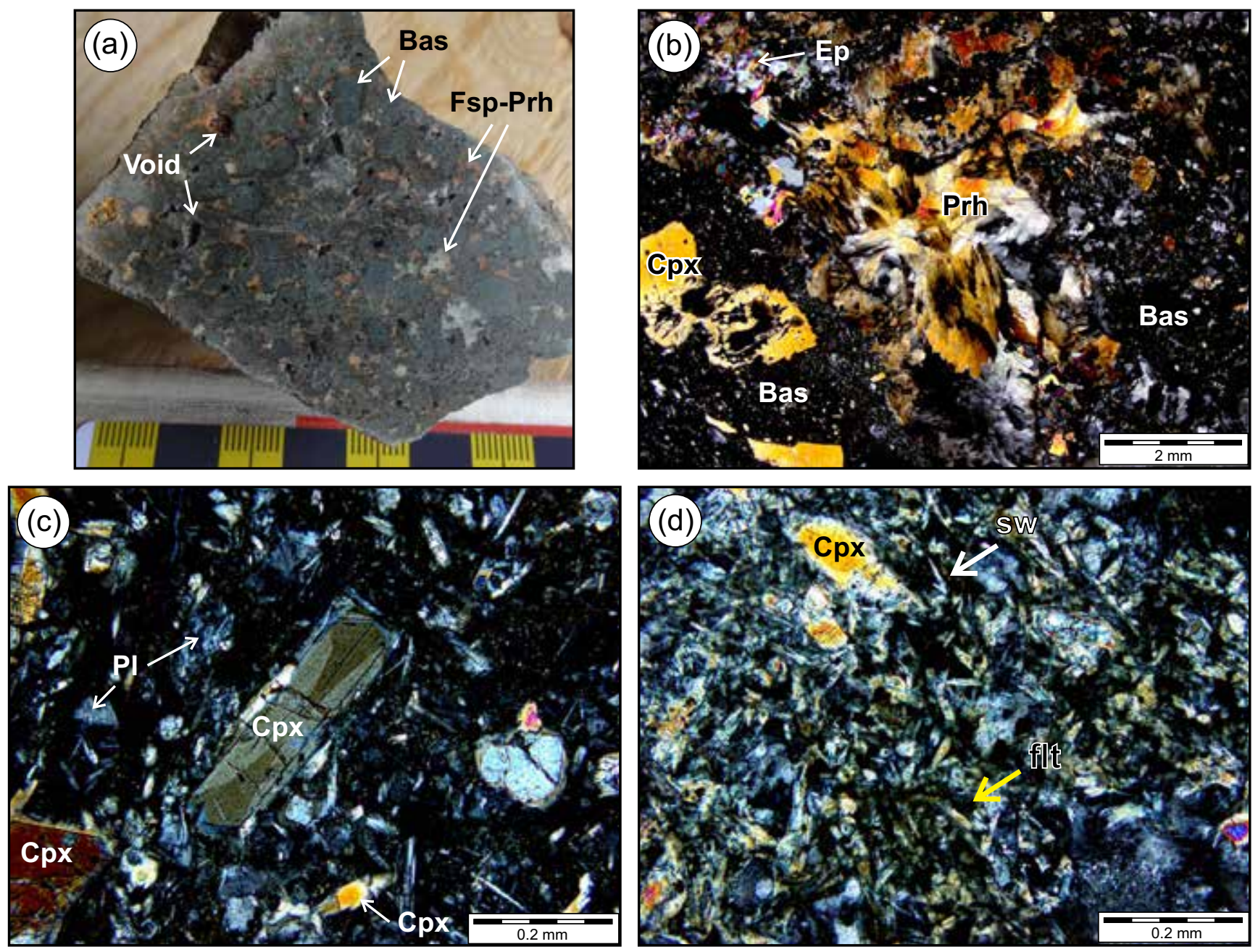

Figure 5. Photograph of hand sample and photomicrographs of thin sections of the Fifields Pit basalt. (a) Rounded to subrounded basalt fragments separated by voids and infillings of feldspar and prehnite. (b) Glassy, clinopyroxene-porphyritic basalt fragments separated by a late, infill-phase comprising prehnite and minor epidote, viewed under crossed polars. (c) Euhedral clinopyroxene crystal with hourglass zoning and thin overgrowth on the upper tip, viewed under crossed polars. (d) Felty-textured clinopyroxene microlites (flt; yellow arrow) and well-preserved swallowtail terminations (sw; white arrow) in basaltic fragment from Fifields Pit basalt, viewed under crossed polars. Bas = basalt fragment; Cpx = clinopyroxene; $\mathrm{Ep}$ = epidote; Fsp = feldspar; $\mathrm{Pl}=$ = plagioclase; Prh = prehnite.

subangular basaltic pebble-sized clasts $(<3 \mathrm{~cm})$ set in a white to pink infill overlies $\sim 50 \mathrm{~m}$ of siltstone above the top of the Trinity facies diamictite (see also Pu et al. 2016). Subtle normal grading within the mafic breccia and the presence of rare grey, pink, and reddish angular siltstone and mudstone clasts $(\leq 1 \mathrm{~cm})$ are consistent with limited transport and re-deposition of the predominantly mafic volcanic debris. The basaltic breccia is overlain by thin-bedded siliceous siltstone and minor tuffaceous rocks.

The basalt clasts are mainly scoriaceous (Fig. 6b), with an average diameter of $\sim 5 \mathrm{~mm}$ but ranging up to $\sim 3 \mathrm{~cm}$. Chlorite and/or calcite amygdales are common. Acicular, elongate clinopyroxene microcrysts, $\sim 100 \mu \mathrm{m}$ in length, are abundant in some of the clasts. The microcrysts are commonly skeletal and some exhibit swallowtail grain terminations (Fig. 6c), indicative of quenching (Wass 1973).
As in the Fifields Pit basaltic conglomerate, the Bonaventure Head breccia consists of mineral phases interpreted to have crystallized from late-stage secondary (meteoric/deuteric?) fluids filling primary pore spaces. At Bonaventure Head, the infilling phases include feldspar, quartz, chlorite, and minor epidote and calcite; prehnite, however, was not observed.

\section{British Harbour basalt}

Basaltic dykes, sills, flows, and pyroclastic rocks occur at British Harbour, along a ridge $5 \mathrm{~km}$ north of British Harbour, on the island of Ireland's Eye, and along the northeastern tip of Random Island (Fig. 4). Mafic breccia is either interbedded with, or occurs as lenses within, medium-grained, grey, cross-stratified sandstone. Normore (2011) interpreted this 

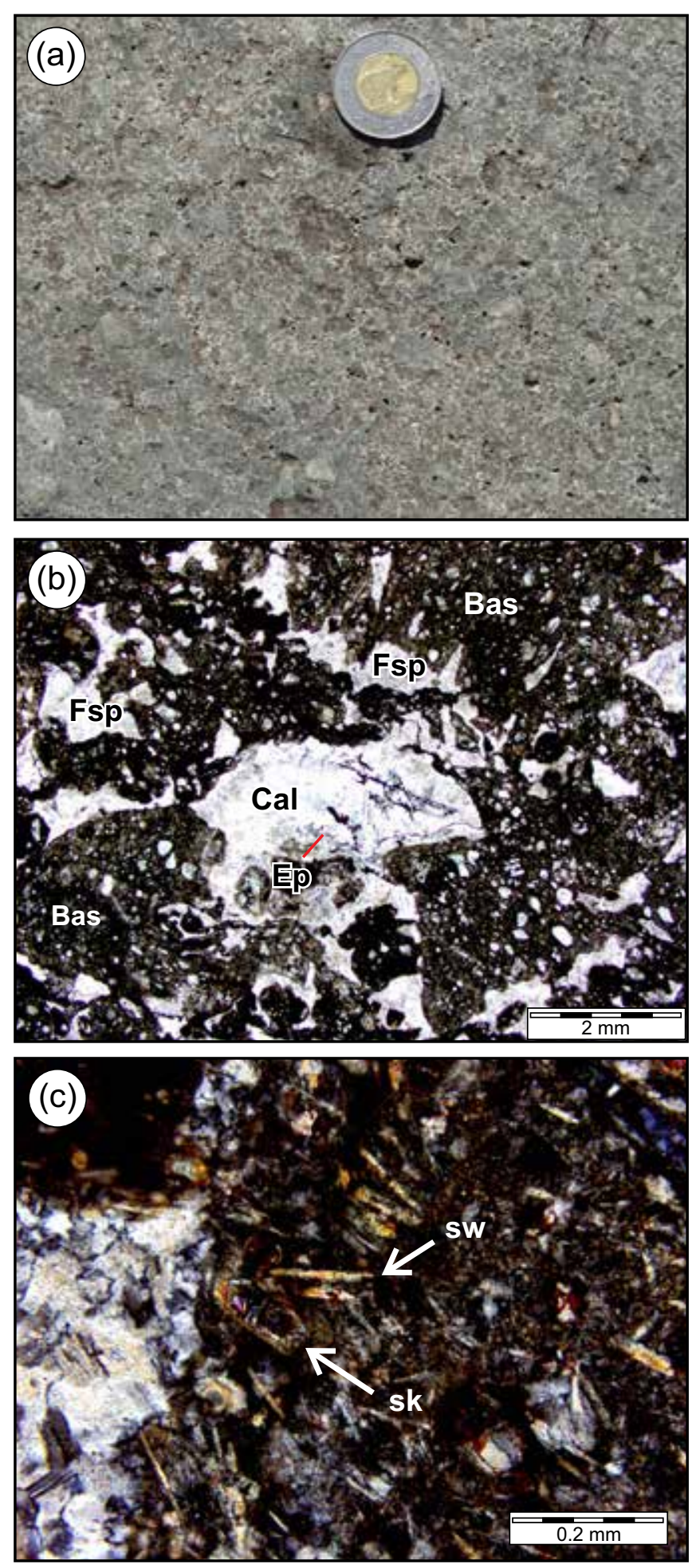

sandstone as Cape Bonavista facies; however, sandstone of the Cape Bonavista facies is elsewhere overlain by the Trinity facies, whereas the stratified sandstone at British Harbour is inferred to stratigraphically overlie the Trinity facies based on field relationships (Fig. 4).

Several mafic dykes (Type 4 dykes of Mills and Sandeman 2017, interpreted as the youngest Ediacaran dykes on the Bonavista Peninsula) intruded the mafic breccia and sand-
Figure 6. Field photograph and photomicrographs of Bonaventure Head basalt. (a) Weathered surface of coastal outcrop showing scoriaceous basalt fragments surrounded by a pink-white void-infill, possibly introduced by secondary fluids. (b) Highly vesicular mafic volcanic fragments separated by possible hydrothermal phases (infilling inter-fragment voids), comprising adularia, calcite, and minor epidote, viewed in plane-polarized light. (c) Detail of mafic volcanic fragment showing skeletal crystals (sk; lower arrow) and deeply embayed swallowtail terminations (sw; upper arrow) of clinopyroxene microcrysts, viewed under crossed polars. Bas = basalt fragment; $\mathrm{Cal}=$ calcite; Ep = epidote; Fsp = feldspar.

stone interbeds and are themselves locally offset by brittle faults (Fig. 7a). On Random Island, grey to reddish, coarsegrained, immature sandstone containing red mudstone ripup clasts (Fig. 7b) is overlain by mafic pyroclastic rocks and flows displaying well-developed flow-top breccia (Fig. 7c). The basalts are overlain by medium-bedded, reddish-weathering, structureless (massive) sandstone, in turn overlain to the south by red pebble conglomerate (Fig. 4). The latter was interpreted by Normore (2012a, b) as upper Crown Hill Formation. Basalts on Ireland's Eye Island include agglomerate containing basaltic lapilli and bombs in a tuffaceous matrix (Fig. 7d), massive basalt flows and interbedded basalt breccia, and red siltstone containing local convolutions and slump folds (Fig. 7e). These rocks are overlain to the south by red sandstone to granule conglomerate, also interpreted by Normore (2012a, b) as upper Crown Hill Formation.

The British Harbour pyroclastic rocks contain abundant, highly vesicular scoria fragments (Fig. 8a), commonly rimmed by black spherules that may have originated as droplets of basaltic liquid, now preserved as volcanic glass (Fig. 8b-c). Amygdales are predominantly filled with chlorite and are locally rimmed by tiny titanite grains (Fig. 8c). Subrounded lithic clasts, feldspar, and less common quartz crystals comprise the groundmass of some pyroclastic rocks, whereas others contain scoriaceous and trachytictextured basalt fragments in a glassy groundmass. Flows contain minor sub- to euhedral plagioclase phenocrysts in a plagioclase-lath-rich, pilotaxitic to trachytic-textured groundmass (Fig. 8d). Subhedral titanite crystals up to 300 $\mu \mathrm{m}$ occur as an early magmatic mineral phase, enveloped by trachytic-textured plagioclase, whereas interstitial titanite occurs as abundant $<40 \mu \mathrm{m}$ anhedral grains (Fig. 8e). Hematite and apatite are also significant accessory phases (Fig. 8f).

\section{LITHOGEOCHEMISTRY}

The chemical compositions of thirty-five samples of basaltic rocks from the four localities discussed above were examined for this study, including nine samples of the previously described alkaline Dam Pond basalt (Mills and 

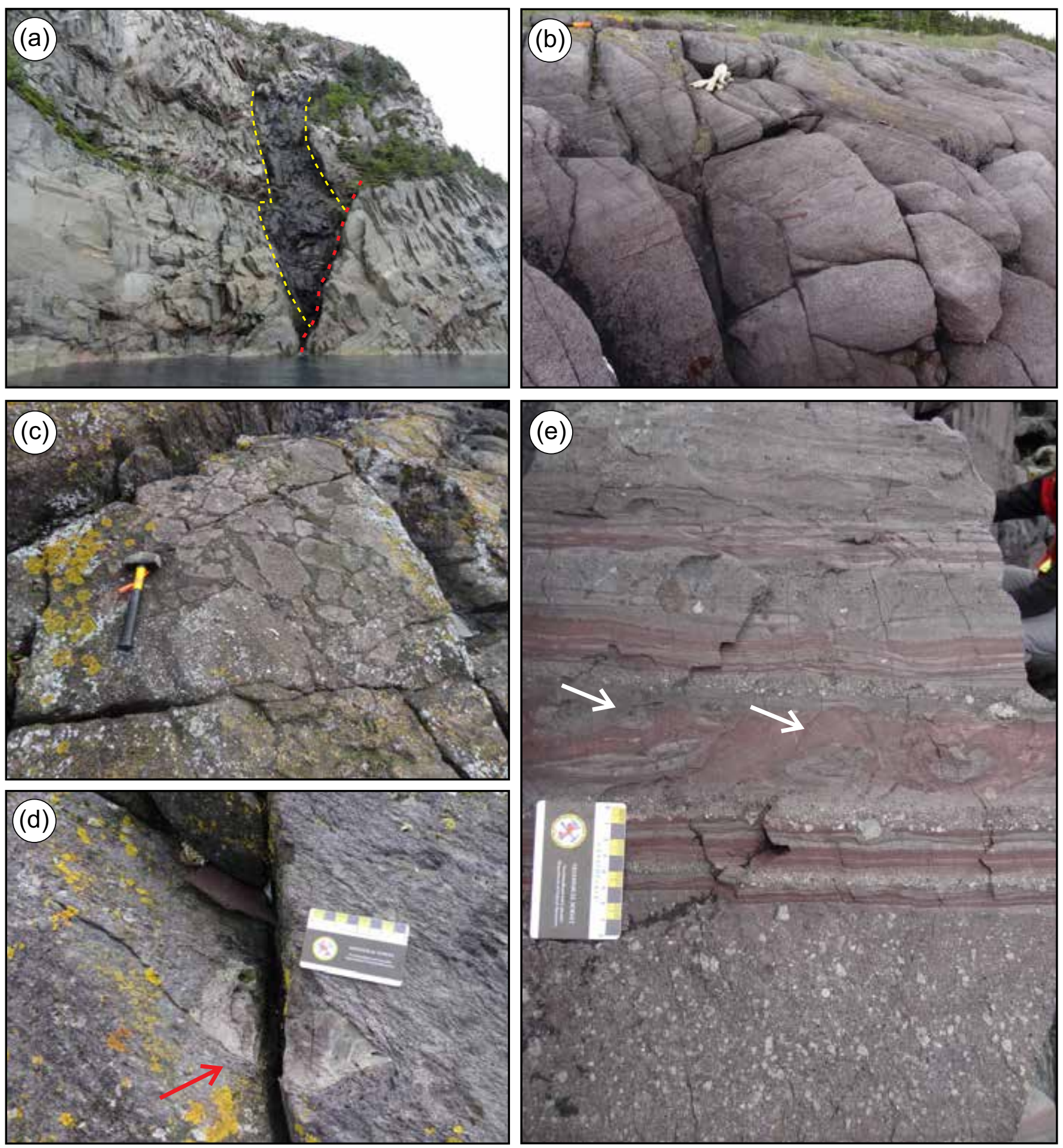

Figure 7. Field photographs of British Harbour basalts. (a) Post-intrusion brittle fault resulting in truncation of a $1.5 \mathrm{~m}$ wide mafic dyke, view to the northeast. (b) Very coarse-grained, thick-bedded, immature sandstone (grit) containing red mudstone rip-up clasts; view to the west. (c) Basaltic flow-top breccia, upper British Harbour basalt unit, northeastern Random Island. (d) Basaltic bomb in mafic pyroclastic rock, northeast tip of Random Island. (e) Interbedded mafic lapilli tuff and red siltstone, showing evidence for slumping between volcanic eruptions (arrows), southwestern Ireland's Eye Island, view to the north.

Sandeman 2015). The single sample from Fifields Pit and the three samples from Bonaventure Head are all basaltic breccia. The preservation of irregular fragment morphology in the Fifields Pit sample indicates little to no post-eruptive transport whereas the Bonaventure Head samples may be redeposited agglomerates. Twenty-two samples from the 

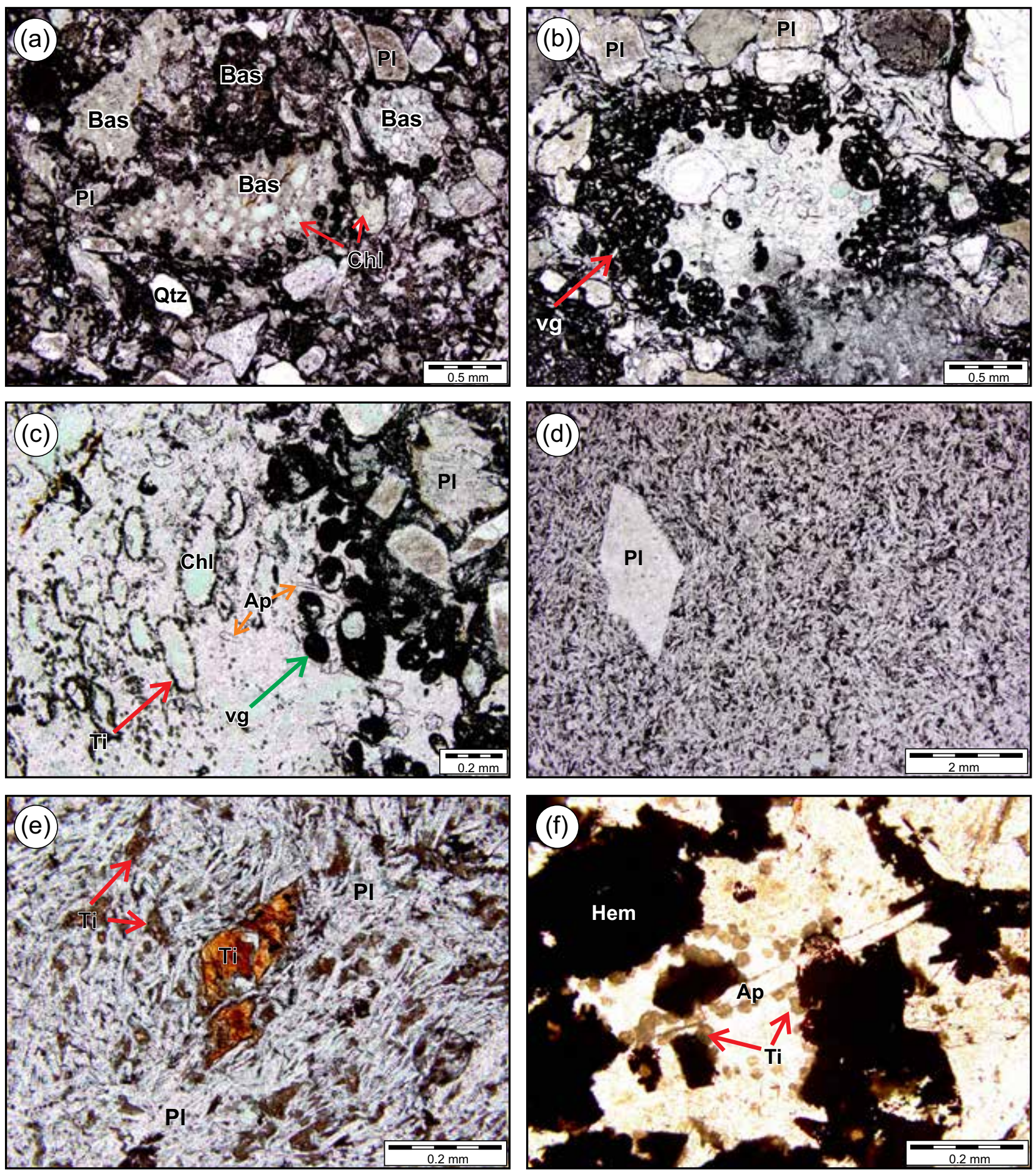

Figure 8. Photomicrographs of British Harbour basalts. (a) Highly vesicular (scoriaceous) basalt fragments in crystal lapilli tuff from southwestern Ireland's Eye Island; chlorite has replaced mafic grains or clasts in the matrix and infills amygdales in basalt fragments. (b) Black spherules of probable volcanic glass (vg; red arrow) rimming scoriaceous basalt fragment in basaltic crystal lithic tuff, southeastern Ireland's Eye Island. (c) Apatite crystals (orange arrows) and chlorite-filled amygdales rimmed by minute titanite crystals ( $\mathrm{Ti}$; red arrow) in scoriaceous basalt fragment, which is itself rimmed by possible volcanic glass spherules (vg; green arrow). The rock is a crystal-lapilli tuff from southwestern Ireland's Eye Island. (d) Variably saussuritized plagioclase phenocryst in weakly trachytic basalt flow from the west side of British Harbour. (e) Large $(200 \mu \mathrm{m})$, subhedral titanite crystal enveloped by flow-textured plagioclase laths, likely an early magmatic phase relative to the interstitial titanite (Ti; red arrows); the rock is a basalt flow from the top of the volcanic sequence at northeastern Random Island. (f) Accessory hematite, apatite and titanite in plagioclase porphyritic basalt flow from the west side of British Harbour. All photomicrographs taken under plane-polarized light. Bas = basalt fragment; $\mathrm{Pl}=$ plagioclase; $\mathrm{Qtz}=\mathrm{quartz}$; $\mathrm{Chl}=$ chlorite; $\mathrm{Ap}=$ apatite; $\mathrm{Ti}=$ titanite; $\mathrm{Hem}=$ hematite . 
British Harbour area (including Random and Ireland's Eye islands) include basalt dykes, flows, as well as tuffs and breccia deposits. Veins, alteration, and weathered surfaces were avoided and efforts were made to collect representative igneous material during bedrock mapping (e.g., a chisel was used to extract a volcanic bomb from an outcrop of basaltic agglomerate). Samples were analyzed by the Geological Survey of Newfoundland and Labrador's chemistry laboratory for determination of their major- and trace-element compositions. Sample preparation and analytical methodologies are outlined by Finch et al. (2018). Sample locations and complete lithogeochemical data are reported in the Appendix. One archival sample (10LN727A) has only a partial set of trace element data.

Rocks of the Avalon terrane are known to have been locally affected by alteration and/or metasomatism (e.g., Hughes and Malpas 1971; O'Brien et al. 1998, 1999; Sparkes and Dunning 2014; Mills and Sandeman 2015). Some of the basalts from Bonavista Peninsula, particularly those from the British Harbour area, exhibit an apparent alteration trend involving the introduction of albite and chlorite, which is typical of seawater interaction at low temperatures (Large et al. 2001; see Fig. 9a). The box plot of Large et al. (2001) uses alteration indexes to depict changes in major element compositions that likely reflect post-magmatic, hydrothermal, and diagenetic alteration, with altered samples extending from the least altered box toward the dominant alteration mineral positions (Fig. 9a). Although only four of our 35 samples plot outside the least-altered box (Fig. 9a), abundances of high field strength (HFSE) and rare earth (REE) elements, which are essentially immobile under most fluidrock interactions (e.g., Pearce and Cann 1973; Wood et al. 1980; Middelburg et al. 1988), are emphasized for petrologic and tectonic interpretations.

\section{Dam Pond basalt}

All nine samples of Dam Pond basalt are alkalic basalts (Fig. 9b). With the exception of the Fifields Pit basalt, these rocks have the lowest $\mathrm{SiO}_{2}, \mathrm{FeO}^{\mathrm{T}}, \mathrm{TiO}_{2}$, and $\mathrm{Zr}$ contents of all the alkaline Bonavista Peninsula basalt samples. Their $\mathrm{Mg \# ,} \mathrm{Cr,} \mathrm{Ni,} \mathrm{Co,} \mathrm{and} \mathrm{V} \mathrm{contents} \mathrm{are} \mathrm{greater} \mathrm{than} \mathrm{those} \mathrm{of}$ the British Harbour basalts, but not as elevated as those of the Fifield Pit and Bonaventure Head basalts (Table 2; Fig. 10). Dam Pond basalt multi-element patterns are steep and smooth, and generally have slightly elevated $\mathrm{Nb}$ relative to Th and La (Fig. 11a). They plot near ocean island basalt (OIB) on most discrimination diagrams (e.g., Figs. 12a, c, d) or in the 'continental' field, near the alkaline field boundary, of Cabanis and Lecolle (1989; Fig. 12b). Their position above the mantle array in $\mathrm{Th} / \mathrm{Yb}$ vs. $\mathrm{Nb} / \mathrm{Yb}$ space (Fig. 12c) indicates minor Th-addition, possibly resulting from lithospheric contamination, consistent with their somewhat variable $\mathrm{Th} / \mathrm{La}$ ratios. Their position in $\mathrm{TiO}_{2} / \mathrm{Yb}$ vs. $\mathrm{Nb} / \mathrm{Yb}$ space (Fig.12d) reflects a relatively deep parental source, one which is deeper than that for normal mid-ocean ridge basalt (NMORB) and enriched mid-ocean ridge basalt (EMORB), approaching the depths of the asthenospheric source for OIB (Pearce 2008).
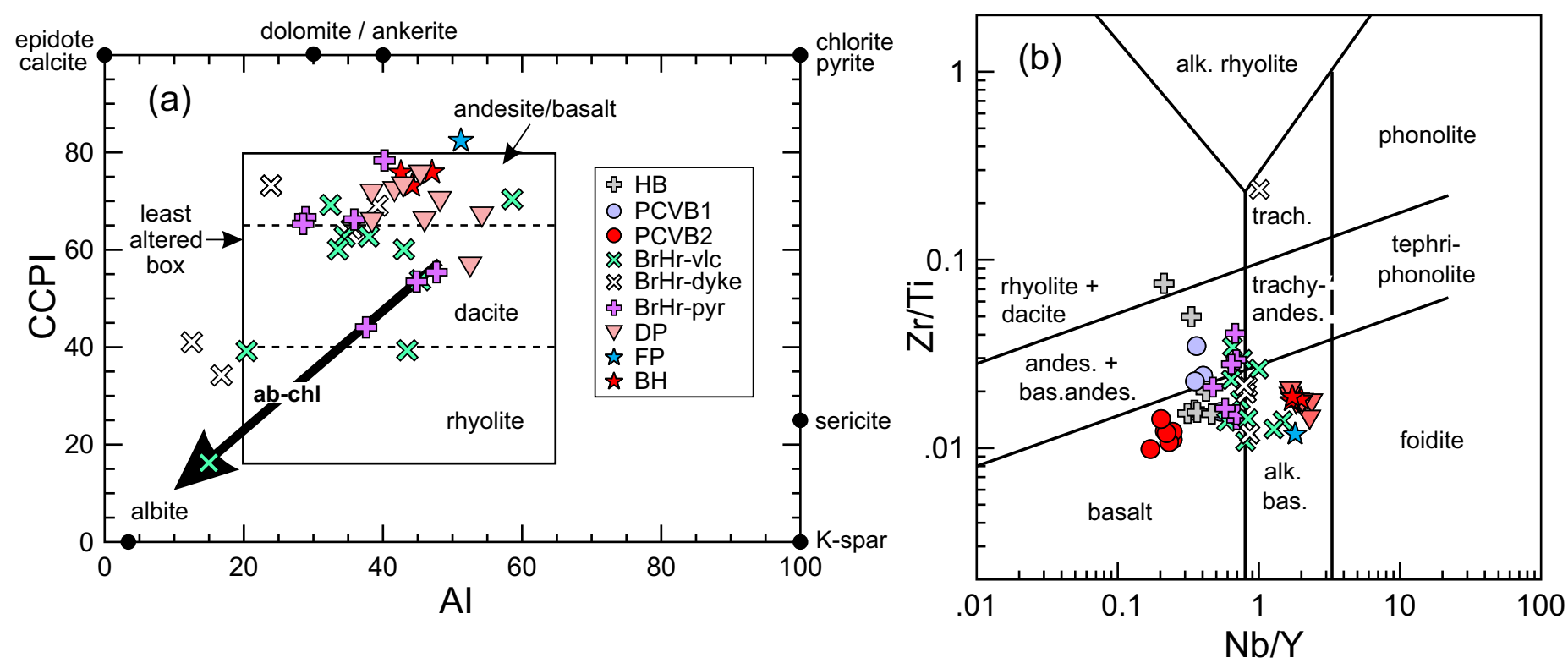

Figure 9. Classification of basaltic rocks from the Bonavista Peninsula area. (a) Alteration box-plot (Large et al. 2001) and (b) Zr/Ti vs. Nb/Y diagram (Pearce 1996). Key: HB = Headland basalt (Cannings Cove Formation); PCVB1 and PCVB2 = basalt series from Plate Cove volcanic belt; BrHr-vlc, BrHr-dyke, BrHr-pyr = basalt flow, dyke and pyroclastic rocks, respectively, of the British Harbour basalts; DP = Dam Pond basalt; FP = Fifields Pit basalt; $\mathrm{BH}=$ Bonaventure Head basalt . $\mathrm{AI}=$ Alteration Index; CCPI = Chlorite-Carbonate-Pyrite Index (as per Large et al. 2001). 
Table 2. Salient geochemical features of the alkaline basalt groups from the Bonavista Peninsula area.

\begin{tabular}{|c|c|c|c|c|c|}
\hline $\begin{array}{c}\text { Geographic } \\
\text { area }\end{array}$ & $\begin{array}{c}\text { Fifields } \\
\text { Pit basalt }\end{array}$ & $\begin{array}{c}\text { Bonaventure } \\
\text { Head basalt }\end{array}$ & $\begin{array}{l}\text { Dam } \\
\text { Pond }\end{array}$ & $\begin{array}{c}\text { BrHr } \\
\text { volcanic }\end{array}$ & $\begin{array}{l}\text { BrHr pyro- } \\
\text { clastic rocks }\end{array}$ \\
\hline $\mathrm{n}$ & 1 & 3 & 9 & 14 & 6 \\
\hline Formation & BHF? & BHF? & $\mathrm{BHF}$ & RHG & RHG \\
\hline $\mathrm{SiO}_{2}$ & 45.6 & 48.0 & 47.6 & 48.8 & 50.1 \\
\hline $\mathrm{Zr}$ & 110 & 201 & 184 & 381 & 282 \\
\hline $\mathrm{Mg \#}$ & 68 & 59 & 57 & 37 & 35 \\
\hline $\mathrm{FeO}^{\mathrm{T}}$ & 9.0 & 8.7 & 8.9 & 10.9 & 10.7 \\
\hline $\mathrm{TiO}_{2}$ & 1.55 & 1.85 & 1.72 & 2.91 & 2.18 \\
\hline $\mathrm{P}_{2} \mathrm{O}_{5}$ & 0.23 & 0.51 & 0.58 & 1.09 & 0.83 \\
\hline $\mathrm{Cr}$ & 825 & 472 & 155 & 18 & 9 \\
\hline $\mathrm{V}$ & 311 & 242 & 204 & 159 & 162 \\
\hline Co & 40 & 47 & 39 & 26 & 27 \\
\hline $\mathrm{Ni}$ & 223 & 211 & 63 & 19 & 17 \\
\hline $\mathrm{Nb}$ & 38 & 42 & 45 & 41 & 26 \\
\hline Th & 3.5 & 7.4 & 6.0 & 3.6 & 4.0 \\
\hline$(\mathrm{La} / \mathrm{Yb})_{\mathrm{CN}}$ & 12.91 & 30.36 & 13.77 & 6.61 & 7.00 \\
\hline$(\mathrm{La} / \mathrm{Sm})_{\mathrm{CN}}$ & 4.31 & 4.63 & 4.05 & 2.15 & 2.43 \\
\hline$(\mathrm{Gd} / \mathrm{Yb})_{\mathrm{CN}}$ & 2.01 & 3.44 & 2.12 & 2.18 & 2.05 \\
\hline $\mathrm{Eu} / \mathrm{Eu}^{*}$ & 0.92 & 0.94 & 0.87 & 0.98 & 1.07 \\
\hline$(\mathrm{Th} / \mathrm{La})_{\mathrm{CN}}$ & 0.83 & 0.73 & 1.12 & 0.70 & 0.80 \\
\hline$(\mathrm{La} / \mathrm{Nb})_{\mathrm{CN}}$ & 0.92 & 2.05 & 1.01 & 1.12 & 1.70 \\
\hline$(\mathrm{Th} / \mathrm{Nb})_{\mathrm{CN}}$ & 0.77 & 1.50 & 1.12 & 0.76 & 1.37 \\
\hline$(\mathrm{Tb} / \mathrm{Yb})_{\mathrm{CN}}$ & 1.68 & 2.49 & 1.67 & 1.78 & 1.65 \\
\hline$\Sigma \mathrm{REE}$ & 155 & 393 & 210 & 276 & 236 \\
\hline
\end{tabular}

Abbreviations: $\mathrm{BrHr}=$ British Harbour, $\mathrm{BHF}=$ Big Head Formation, RHG

= Rocky Harbour Group

\section{Fifields Pit basalt}

Although only one sample of basaltic conglomerate was collected from the Fifields Pit area, it significantly represents the only volcanic deposit currently known in that part of Bonavista Peninsula (Fig. 3). Based on its incompatible trace element composition, the Fifields Pit rock is an alkali basalt (Fig. 9b). It has the highest $\mathrm{Mg \#}, \mathrm{Cr}$ and $\mathrm{Ni}$, and the lowest $\mathrm{SiO}_{2}$ and $\mathrm{Zr}$ contents, and is therefore the most primitive of the alkali basalt samples from the Bonavista Peninsula (Table 2; Fig. 10). Its multi-element pattern is steep, with notable negative anomalies for $\mathrm{Zr}$, Hf, and P (Fig. 11a). Despite having higher $\mathrm{MgO}$ and lower $\mathrm{Zr}$ content, it is chemically more similar to the Dam Pond basalts than to the other alkali basalts investigated herein (Figs. 11-12). On most tectonic discrimination diagrams, the Fifields Pit basalt is similar in composition to OIB (Fig. 12). Its position within the mantle array in $\mathrm{Th} / \mathrm{Yb}$ vs. $\mathrm{Nb} / \mathrm{Yb}$ space indicates negligible lithospheric contamination. In $\mathrm{TiO}_{2} / \mathrm{Yb}$ vs. $\mathrm{Nb} / \mathrm{Yb}$ space, it plots just above the shallow mantle NMORB-EMORB array, within the OIB field (Figs. 12c-d).

\section{Bonaventure Head basalt}

Based on their incompatible trace element compositions, the three samples from the lower, middle, and upper parts of the $\sim 25 \mathrm{~m}$-thick tuffaceous breccia at Bonaventure Head are alkali basalt (Fig. 9b), transitional calc-alkalic-continental basalt (Fig. 12b), or OIB (Figs. 12a, c, d). Their $\mathrm{SiO}_{2}, \mathrm{FeO}^{\mathrm{T}}$, $\mathrm{TiO}_{2}, \mathrm{P}_{2} \mathrm{O}_{5}$, and $\mathrm{Zr}$ abundances are comparable to those of the Dam Pond basalts (Table 1; Fig. 10), and markedly lower than those of the British Harbour basalts. Like the Dam Pond basalt, the Bonaventure Head basalt has relatively high $\mathrm{Mg \#}$ (Fig. 10a; Table 1). Cr and Ni contents are higher in the Bonaventure Head basalts than in the Dam Pond basalts, and considerably higher than those of the British Harbour basalts (Fig. 10e, f; Table 1). The Bonaventure Head basalts have the steepest multi-element patterns [average $\left.(\mathrm{La} / \mathrm{Yb})_{\mathrm{CN}}=30\right]$ of all basalts from the Bonavista Peninsula (Table 2), and have notable $\mathrm{Nb}, \mathrm{Zr}, \mathrm{Hf}$, and $\mathrm{P}$ troughs (Fig. 11b) and minor negative Ti anomalies. They are similar to OIB on most discrimination diagrams (Figs. 12a, c, d) but plot slightly above the mantle array in $\mathrm{Th} / \mathrm{Yb}$ vs. $\mathrm{Nb} /$ $\mathrm{Yb}$ space (Fig. 12c), indicating minor lithospheric/crustal contamination.

\section{British Harbour basalt}

The British Harbour basalts $(\mathrm{n}=22)$ are subdivided into two lithological and lithogeochemical groups: British Harbour volcanic rocks ( $\mathrm{n}=15 ; 5$ dykes, 9 flows and one basalt bomb extracted from an agglomerate); and British Harbour pyroclastic rocks ( $n=7$; tuffaceous, pyroclastic and breccia deposits all of which may contain a minor component of epiclastic material; e.g., Figs. 7d, e).

The British Harbour basalts are weakly alkaline in terms of their incompatible trace element compositions, although many samples plot outside the alkaline field and close to the basalt-alkali basalt divide (Fig. 9b). Relative to other alkali basalts from the Bonavista Peninsula, they have lower Mg\#'s, very low $\mathrm{Ni}, \mathrm{Cr}$, and variable $\mathrm{V}$ and Co contents, with higher $\mathrm{FeO}^{\mathrm{T}}, \mathrm{TiO}_{2}, \mathrm{P}_{2} \mathrm{O}_{5}$, and $\mathrm{Zr}$ abundances (Fig. 10; Table 2), and are therefore more fractionated mafic magmas. The British Harbour pyroclastic rocks have comparable $\mathrm{Mg}, \mathrm{SiO}_{2}, \mathrm{Co}$, and $\mathrm{Ni}$ contents, lower $\mathrm{TiO}_{2}, \mathrm{P}_{2} \mathrm{O}_{5}, \mathrm{Zr}$, and $\mathrm{Nb}$ contents, and slightly higher Th contents relative to the volcanic rocks (Table 2; Fig. 10). The British Harbour volcanic rocks display a concave-downward pattern in the Th-Nb-light-REE portion of the multi-element plot (Fig. 11c), similar to the Fifields Pit basalt and most of the Dam Pond basalt samples, whereas the pyroclastic rocks and Bonaventure Head basalt have small $\mathrm{Nb}$ troughs (Fig. 11d). In terms of key element ratios, $(\mathrm{La} / \mathrm{Nb})_{\mathrm{CN}}$ and $(\mathrm{Th} / \mathrm{Nb})_{\mathrm{CN}}$ values are either close to or less than one for the British Harbour volcanic rocks, Fifields Pit and Dam Pond basalts, and are significantly higher for the British Harbour pyroclastic rocks and Bonaventure Head basalt (Table 1). The British Harbour basalts have higher Y (Fig. 12b), and lower $\mathrm{La} / \mathrm{Yb}$ and $\mathrm{Nb} / \mathrm{Yb}$ (Figs. 12c-d) than the Fifields Pit, Bonaventure Head, and Dam Pond basalts, and are therefore more EMORB-like (Fig. 12a, c, d). The British Harbour volcanic rocks plot within the mantle array and close to EMORB in $\mathrm{Th} / \mathrm{Yb}$ vs. $\mathrm{Nb} / \mathrm{Yb}$ space, whereas the 

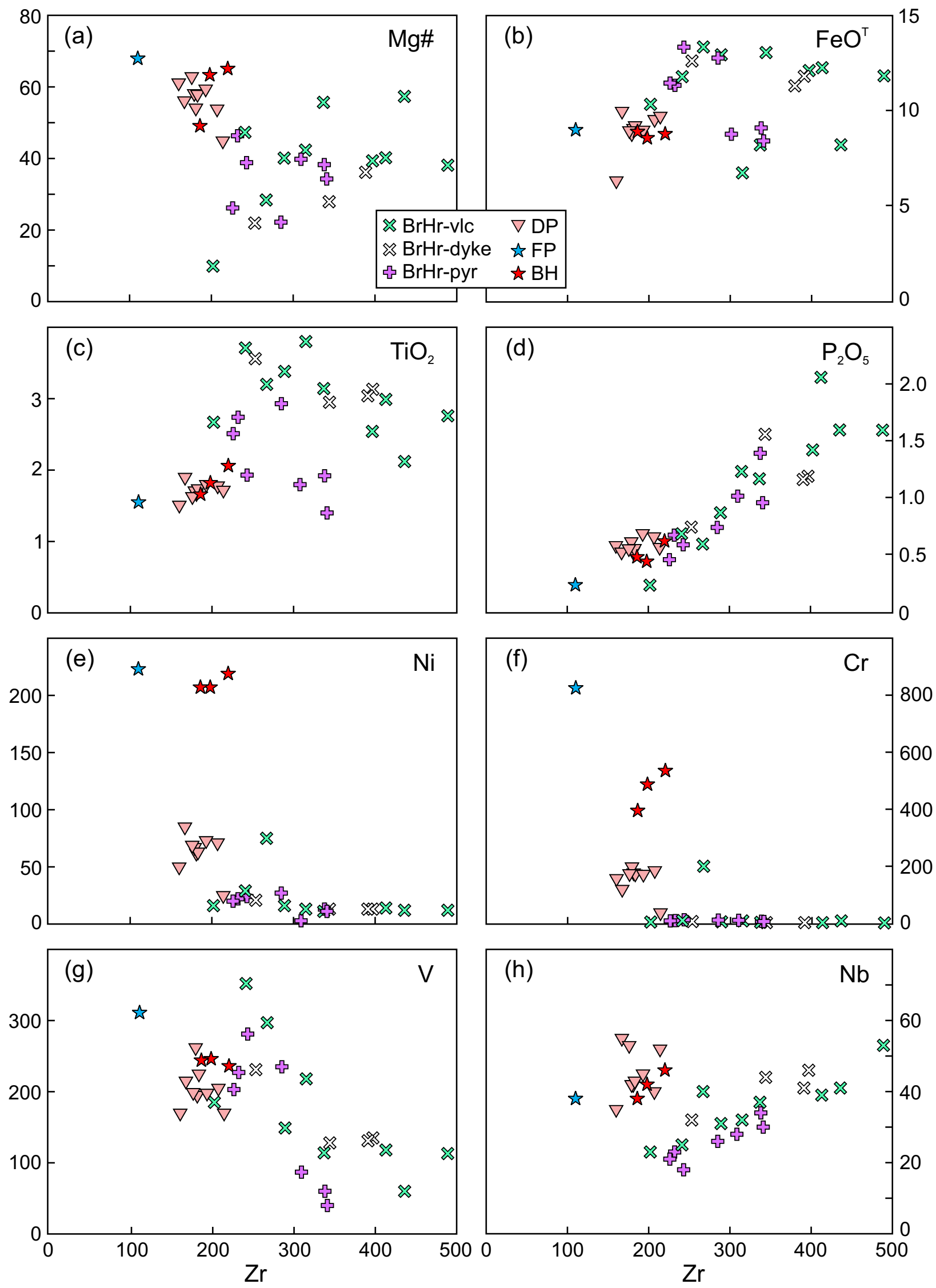

Figure 10. Binary elemental plots for alkali basalts of the Bonavista Peninsula area. (a) $\mathrm{Mg}^{2}$ vs. $\mathrm{Zr}$. (b) $\mathrm{FeO}^{\mathrm{T}}$ vs. $\mathrm{Zr}$. (c) $\mathrm{TiO}_{2}$ vs. Zr. (d) $\mathrm{P}_{2} \mathrm{O}_{5}$ vs. Zr. (e) Ni vs. Zr. (f) Cr vs. Zr. (g) V vs. Zr. (h) Nb vs. Zr. Abbreviations are as in Figure 9. 

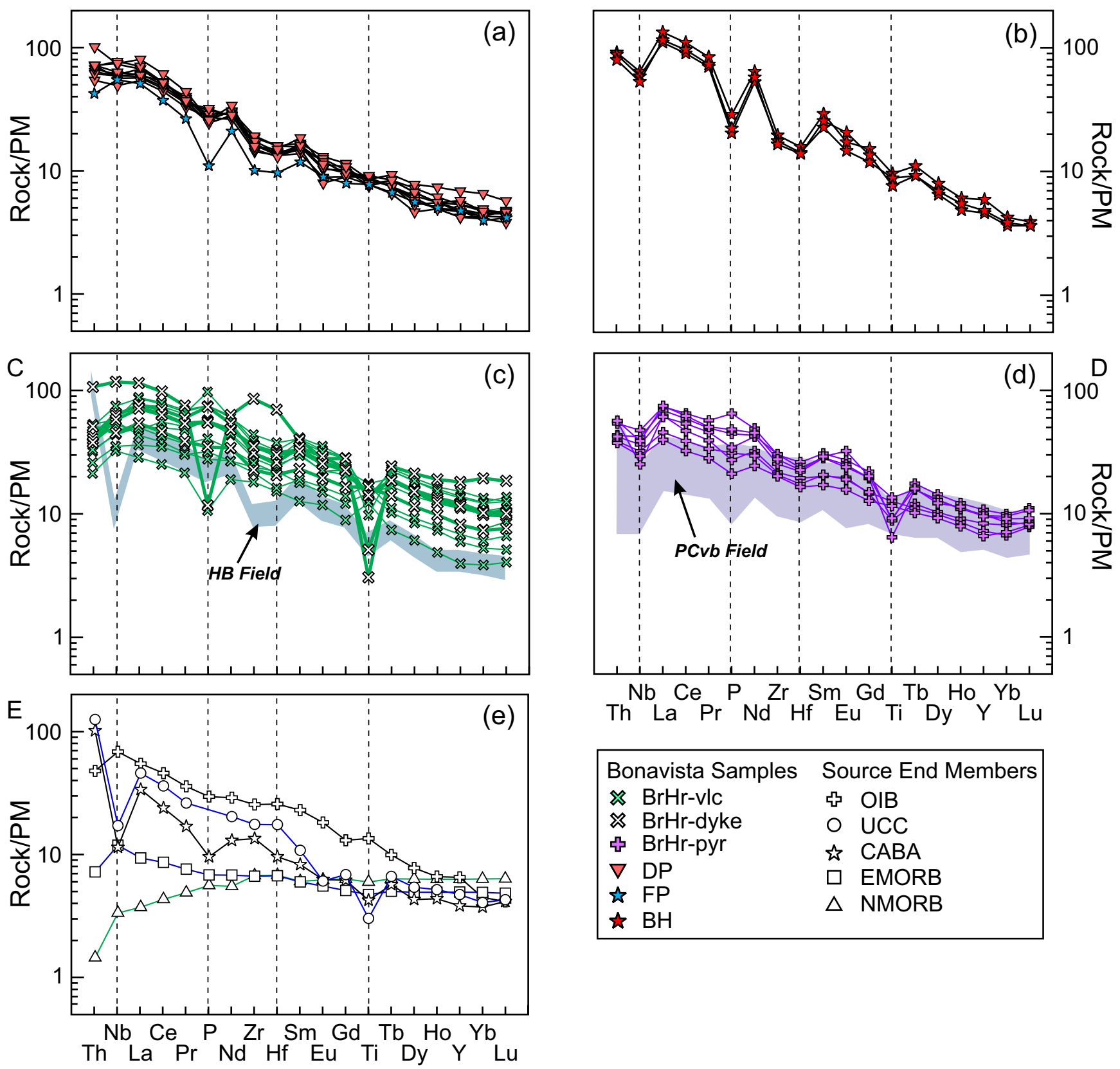

\begin{tabular}{|c|c|}
\hline Bonavista Samples & Source End Members \\
\hline$\bowtie \mathrm{BrHr}-\mathrm{vlc}$ & њ OIB \\
\hline$\bowtie$ BrHr-dyke & O UCC \\
\hline њ BrHr-pyr & ts $\mathrm{CABA}$ \\
\hline$\nabla$ DP & $\square$ EMORB \\
\hline 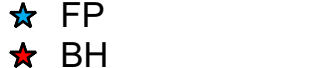 & $\triangle$ NMORB \\
\hline
\end{tabular}

Figure 11. Primitive mantle-normalized multi-element plots for alkaline mafic volcanogenic rocks from the Bonavista Peninsula area. (a) through (d) Petrogenetic groups from the study area, as per key, lower right; (normalizing values from Sun and McDonough 1989). (e) Representative multi-element patterns for possible mantle end members. CABA = Calcalkaline basaltic andesite (CA 172; Guiseppe et al. 2018); NMORB, EMORB and OIB are normal mid-ocean ridge basalt, enriched mid-ocean ridge basalt, and ocean-island basalt, respectively (Sun and McDonough 1989); UCC = average upper continental crust (Rudnick and Gao 2003). Other abbreviations are as in Figure 9.

pyroclastic rocks plot above the mantle array (Fig. 12c), as expected for rocks containing a small component of 'continental' epiclastic material (Fig. 13c).

\section{DISCUSSION}

Basalts from Bonavista Peninsula are generally weakly altered to fresh, alkalic to transitionally alkalic mafic rocks, comprising two lithogeochemically distinct suites. The Dam Pond - Fifields Pit - Bonaventure Head samples occur mainly within greenish siltstones and sandstones of either the Big Head Formation or of the post-Trinity facies units (hereafter referred collectively as Big Head Formation basalts), whereas the British Harbour - Random Island Ireland's Eye Island basalts occur near the top of the coarsening-upward Rocky Harbour Formation (Normore 2012a, b). Fine-grained siliciclastic rocks of both the Big Head 

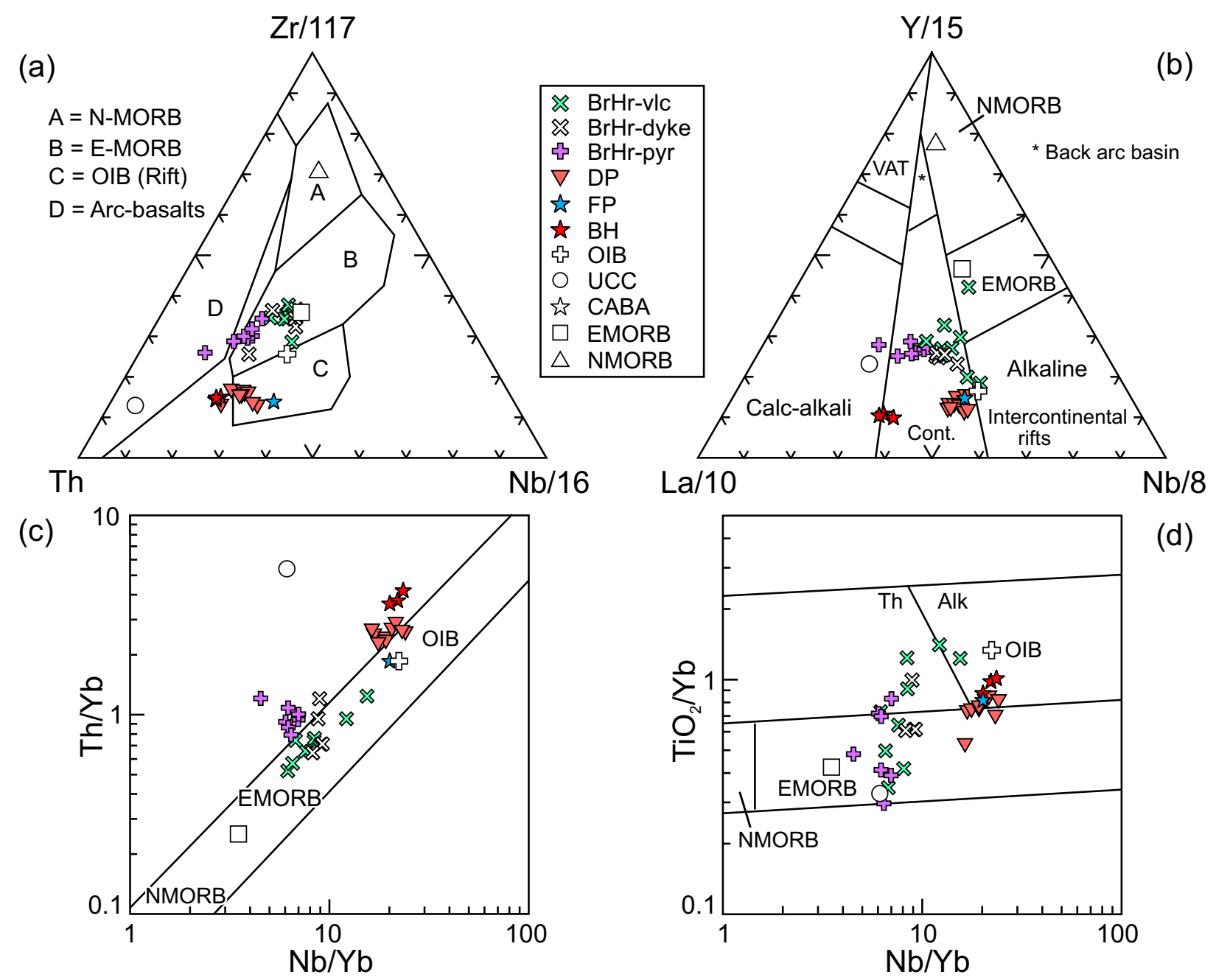

(d)

Figure 12. Immobile element tectonic discrimination diagrams for mafic alkaline rocks from the Bonavista Peninsula area. (a) Th - Zr/117- Nb/16 (Wood 1980). (b) La/10 - Y/15 - Nb/8 (Cabanis and Lécolle 1989). (c) Th/Yb vs. Nb/Yb (Pearce 2008). (d) $\mathrm{TiO}_{2} / \mathrm{Yb}$ vs. $\mathrm{Nb} / \mathrm{Yb}$ (Pearce 2008). Abbreviations are as in Figures 9 and 11.

Formation and post-Trinity facies units likely reflect a quiescent depositional setting whereas coarse clastic rocks of the Rocky Harbour Formation reflect high-energy, likely shallow marine to terrestrial settings. The two formations are interpreted as coevally deposited, proximal (coarse clastic facies of the Rocky Harbour Formation) and distal (Big Head Formation) facies, as both contain the Trinity diamictite (Fig. 2). The two units may be interdigitated, and their constituent lithofacies were controlled, in part, by proximity to topographically rugged volcanic edifices along peri-glacial and extensional, continental and/or island arc margins.

The British Harbour basalts have lower $\mathrm{MgO}, \mathrm{Mg}$ 's $\mathrm{s}, \mathrm{Cr}$, and $\mathrm{Ni}$ and elevated $\mathrm{FeO}^{\mathrm{T}}, \mathrm{TiO}_{2}, \mathrm{P}_{2} \mathrm{O}_{5}$, and $\mathrm{Zr}$ and are therefore more evolved fractionated mantle-derived magmas relative to the Big Head Formation basalts. The British Harbour basalts also differ from the latter by their distinctly elevated $\mathrm{Zr} / \mathrm{Nb}$ ratios, which are higher than average OIB (Sun and McDonough 1989; Fig. 13a). The British Harbour basalts have higher $\mathrm{Zr} / \mathrm{Nb}$ (Fig. 13b), slightly lower $\mathrm{Nb} / \mathrm{Y}$ (Fig. 13d), and significantly lower $(\mathrm{La} / \mathrm{Sm})_{\mathrm{CN}}$ (Fig. 13e) than the
Big Head Formation basalts, indicating that the two suites likely originated from two distinct mantle sources (see Pearce and Norry 1979), with the former more EMORB-like and the latter more OIB-like (Fig. 12a, c, d).

\section{Role of 'contamination' in the petrogenesis of alkaline rocks from the Bonavista Peninsula}

Of the collective Big Head Formation basalts, the Bonaventure Head basalt has the highest mantle-incompatible trace element ratios (Table 1), with the exception of Th/La which is higher in the other Big Head Formation basalts. The low Th/ La ratio, modest $\mathrm{Nb}, \mathrm{P}, \mathrm{Zr}$ and $\mathrm{Hf}$ troughs (Fig. 11), elevated $\mathrm{Th} / \mathrm{Yb}$ (Fig. 12c) and low Nb/Th (Fig. 13c) are consistent with lithospheric/crustal contamination (see Pearce 2008). Contamination likely occurred post-eruption, during subsequent reworking and incorporation of epiclastic material, rather than in the mantle source or during ascent to the surface, as indicated by minor mudstone and siltstone clasts and subtle normal grading within the Bonaventure Head basalt 

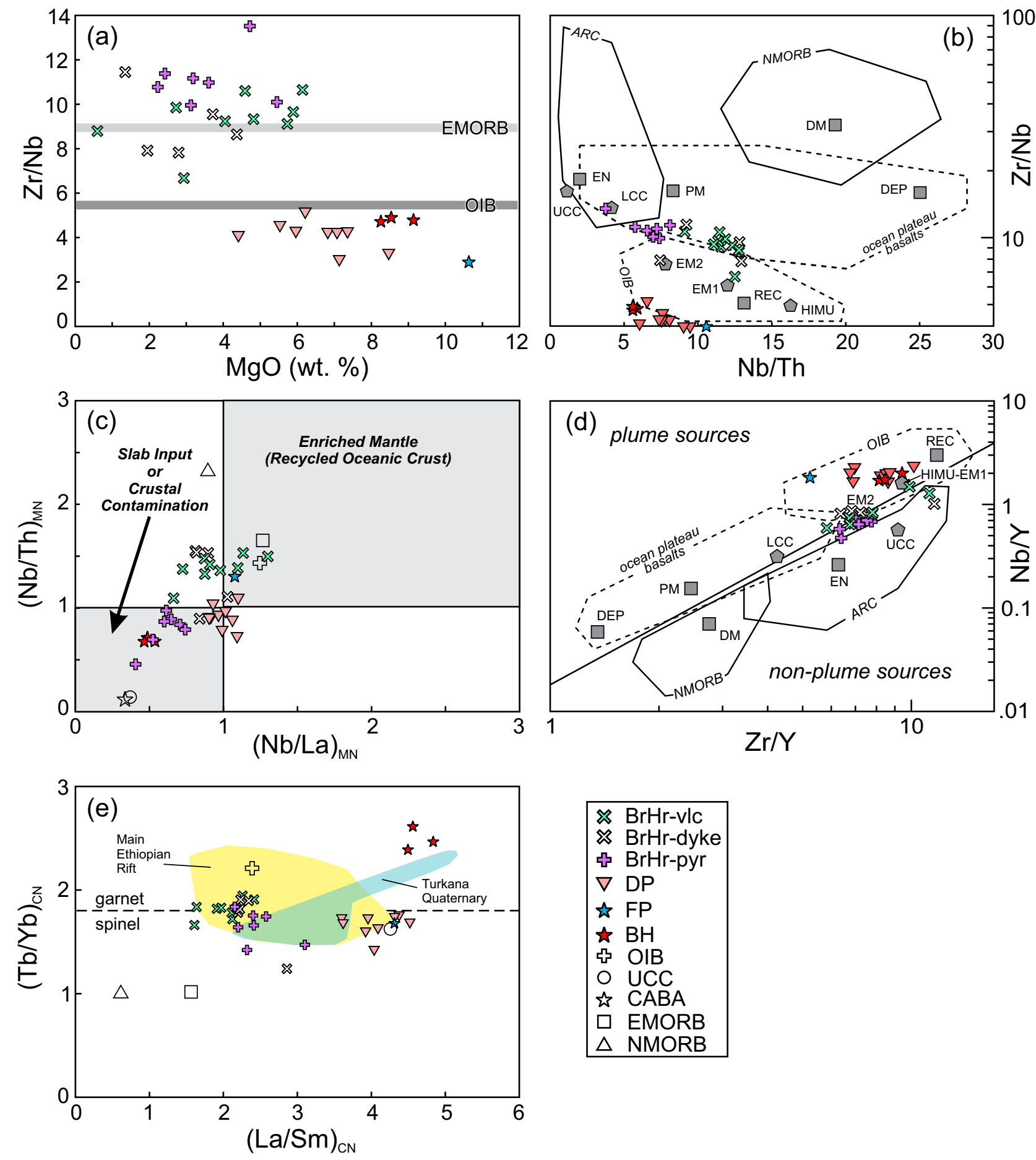

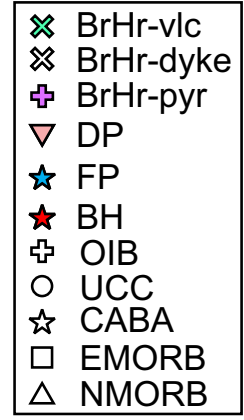

Figure 13. Selected incompatible element ratio-ratio diagrams for mafic alkaline rocks from the Bonavista Peninsula area. (a) $\mathrm{Zr} / \mathrm{Nb}$ vs. $\mathrm{MgO}$ with average OIB and $\mathrm{EMORB}$ (Sun and McDonough 1989) shown as lines. (b) $\mathrm{Zr} / \mathrm{Nb}$ vs. Nb/Th with fields and end-members from Condie (2005) (Abbreviations: UCC, LCC = upper and lower continental crust; PM = primitive mantle; $\mathrm{DM}=$ shallow depleted mantle; HIMU = high $\mathrm{mu}(\mathrm{U} / \mathrm{Pb})$ mantle source; EM1 and EM2 = enriched mantle sources; ARC $=$ arc-related basalts; NMORB $=$ normal mid-ocean ridge basalt; OIB = ocean island basalt; DEP = deep depleted mantle; $\mathrm{EN}=$ enriched component; REC = recycled component). (c) $(\mathrm{Nb} / \mathrm{Th})_{\mathrm{MN}} \mathrm{vs}$. $(\mathrm{Nb} / \mathrm{La})_{\mathrm{MN}}$ with fields from Piercey et al. (2006). (d) $\mathrm{Nb} / \mathrm{Y}$ vs. $\mathrm{Zr} / \mathrm{Y}$ with fields and end-members from Condie (2005). (e) $(\mathrm{Tb} / \mathrm{Yb})_{\mathrm{CN}} \mathrm{vs}$. $(\mathrm{La} / \mathrm{Sm})_{\mathrm{CN}}$ with fields for Main Ethiopian Rift and Turkana Quaternary volcanic rocks and line for garnet- vs. spinel-dominated melting from Rooney et al. (2010 and references therein). CN denotes chondrite-normalized; MN denotes primitive mantlenormalized (values of Sun and McDonough 1989). Other abbreviations are as in Figures 9 and 11. 
breccia. Low $(\mathrm{Th} / \mathrm{Nb})_{\mathrm{CN}}$ (Table 1), Th/Yb (Fig. 12c) and slightly elevated $(\mathrm{Nb} / \mathrm{Th})_{\mathrm{MN}}$ (Figs. 13b-c) and $(\mathrm{Nb} / \mathrm{La})_{\mathrm{MN}}$ (Fig. 13c), collectively indicate minor to negligible lithospheric/crustal contamination in the Dam Pond and Fifields Pit basalts. Like the Bonaventure Head basalt breccia, the British Harbour pyroclastic rocks similarly show evidence of contamination (Fig. 13c), including higher $(\mathrm{Th} / \mathrm{Nb})_{\mathrm{CN}}$ and $(\mathrm{La} / \mathrm{Nb})_{\mathrm{CN}}$ (Table 1) and modest $\mathrm{Nb}$ troughs (Fig. 11d), consistent with the minor epiclastic component observed in these rocks (e.g., Fig. 7c). The higher Th content and nominal $\mathrm{Nb}$ troughs of the British Harbour pyroclastic rocks are therefore interpreted to have been derived through physical entrainment of epiclastic fragments into the dominantly pyroclastic detritus during or shortly after eruption. This interpretation is in contrast to an origin via a 'slab component' contribution to the parental magmas in a suprasubduction setting, or to crustal/lithospheric assimilation during their ascent (see Pearce 2008 and Piercey et al. 2006).

\section{Depth of mantle sources for alkaline rocks from the Bonavista Peninsula}

Strongly elevated $(\mathrm{La} / \mathrm{Sm})_{\mathrm{CN}},(\mathrm{Tb} / \mathrm{Yb})_{\mathrm{CN}}$ and $\Sigma \mathrm{REE}$ (Table 1) suggest that the Bonaventure Head basalt, in particular, represents the final crystallization product of a small degree partial melt derived from an enriched, deep asthenospher-ic source, similar to that of OIB in an oceanic setting or to basalts of the Main (continental) Ethiopian Rift (Fig. 13e; Pearce 1996; Rooney 2010). These low degree partial melts likely ascended along deep-seated, pre-existing structures in the lithosphere. The low HREE abundances $(<\mathrm{NMORB})$ and elevated $(\mathrm{Tb} / \mathrm{Yb})_{\mathrm{CN}}(\sim 1.6-2.5$; Table 1$)$ of the British Harbour and Bonaventure Head basalts are chemical characterist ics attributed to the preferential incorporation of $\mathrm{Y}$ and the HREE into garnet during partial melting and therefore suggest that their primary mantle sources were garnet-bearing (see Rooney 2010 and references therein) (Fig. 13e). The lower $(\mathrm{Tb} / \mathrm{Yb})_{\mathrm{CN}}$ ratios of the Dam Pond and Fifields Pit basalts indicates shallower melting, transitioning from the garnet-bearing peridotite facies upwards into the spinel stability field (Fig. 13e). Although the depth of transition from spinel- to garnet-stable peridotite is not precisely constrained, abundant experimental evidence suggests that it occurs in the range of 1.5 to $2 \mathrm{GPa}(\sim 60-80 \mathrm{~km}$ : see Benxun et al. 2013; Niu et al. 2011). Moreover, if a relatively hot geothermal gradient is invoked $\left(\sim 60 \mathrm{~mW} / \mathrm{m}^{2}\right)$, a situation that is likely in an area of extending lithosphere, then garnet may coexist with spinel over a wide stability interval (10-15 km) at depths of 50-70 km (Ziberna et al. 2013). The steep HREE patterns and elevated $(\mathrm{Tb} / \mathrm{Yb})_{\mathrm{CN}}$ ratios for the Bonavista alkali basalts indicate the presence of garnet in the mantle source and likely constrain the depth of generation of the primitive Bonavista Peninsula alkaline basaltic magmas to the garnet-spinel transition zone, corresponding to depths of $\sim 50-90 \mathrm{~km}$. The thickness of the Avalonian lithosphere during the Ediacaran is currently unconstrained.

\section{Tectonic setting of alkaline volcanism in the Bonavista Peninsula}

Basalts of both the Big Head and Rocky Harbour formations, excluding those affected by crustal/lithospheric contamination, are characterized by steep, smooth multielements patterns with LREE-enrichment, high HFSE contents, and slightly elevated $\mathrm{Nb}$ content relative to $\mathrm{Th}$ and La (Fig. 11a, c), characteristic of within-plate basalts, OIB, or alkaline lamprophyres (e.g., Sun and McDonough 1989; Pearce 1996; Piercey et al. 2006; Rock 1991). Such rocks are derived from incompatible element-enriched mantle sources such as mantle plumes or at plate-margin environments under extension (van Staal et al. 1991; Piercey et al. 2006; Rooney et al. 2010; Matton and Jébrak 2009). The low volume of alkaline magmatism on the Bonavista Peninsula and their association with cross-stratified sandstone in an upward-coarsening, shallow marine to terrestrial sequence are consistent with a continental arc or margin under extension (see also van Staal et al. 1991).

The slab influence evident in the ca. $600 \mathrm{Ma}$ calc-alkaline Headland basalts (Fig. 3 and HB field in Fig. 11c; see also Mills and Sandeman 2015) decreased through time. A minor slab influence is apparent in the continental tholeiites of the ca. 590 Ma Plate Cove volcanic belt (PCvb field in Fig. 11d) and is essentially absent in later (ca. $580 \mathrm{Ma}$ and younger) alkali basalt magmatism (Big Head and British Harbour ba-salts); the latter are comparable to those associated with the Mesozoic opening of the North Atlantic (e.g., Matton and Jébrak 2009). Post-subduction tectonomagmatism (post ca. $600 \mathrm{Ma}$ ) likely involved slab rollback and possibly delamination to generate the continental tholeiites of the ca. 592 Ma Plate Cove volcanic belt. Subsequent magmatic underplating produced low degree partial melts of the asthenosphere that accumulated along pre-existing deep-seated faults prior to their emplacement within the Big Head and Rocky Harbour formations. The chemical differences between the primitive Big Head Formation basalts and the more evolved British Harbour basalts, and the temporal gap evident based on their stratigraphic positions, are consistent with episodic extensional tectonics with stalling of British Harbour parental magmas thus allowing time for the precursor magmas to evolve within the crust prior to emplacement.

\section{Timing of extensional volcanism in the Bonavista Peninsula}

Earliest extensional magmatism in the Bonavista Peninsula area includes continental tholeiite (Mills and Sandeman 2015) and weakly alkaline rhyolite (Mills 2020) of the Plate Cove volcanic belt, loosely constrained at ca. 592-591 Ma (Mills et al. 2017) based on the ages of tuffs from the western and eastern margins of the belt (see Fig. 3). The change from subduction-related to extensional magmatism likely occurred earlier, perhaps shortly after eruption of the ca. 600 Ma calc-alkaline Headland basalts (Mills 2019; Mills 
et al. 2016b) assigned to Cannings Cove Formation, basal Musgravetown Group. Based on the stratigraphic position of Dam Pond basalt below the Trinity facies on the northeastern Bonavista Peninsula (Figs. 2-3), mafic alkaline magmatism commenced prior to deposition of the glacial Trinity facies, constrained to ca. $580 \mathrm{Ma}$ at Old Bonaventure $(\mathrm{Pu}$ et al. 2016; see Fig. 3). Whether or not heat associated with ca. 592-580 Ma magmatism helped to trigger deglaciation associated with the ca. $580 \mathrm{Ma}$ Gaskiers event remains to be demonstrated here, but has been suggested in a global context (Youbi et al. 2020). Basaltic rocks at Fifields Pit and Bonaventure Head occur above the Trinity facies and are therefore interpreted to be younger than $580 \mathrm{Ma}$. The British Harbour basalts occur even higher in the stratigraphy, near the top of the Rocky Harbour Formation (Figs. 3-4; Table 1; see also Normore 2012a, b), and are therefore considered to be younger still. Felsic alkaline volcanism of the Rocky Harbour Formation has been dated at ca. $569 \mathrm{Ma}$ (Mills et al. 2020) $60 \mathrm{~km}$ to the northwest, near Content Reach (Fig. 1), further indicating the longevity and episodic nature of extensional magmatism during the Ediacaran in the northwestern Avalon terrane of Newfoundland.

\section{Implications for interpretation of the Musgravetown Group}

The Musgravetown Group was initially defined by Hayes (1948) to include a thick succession of mainly coarse clastic sedimentary rocks and interbedded volcanic rocks that unconformably overlie the turbidite-dominated Connecting Point Group (Hayes 1948) and are unconformably overlain by mainly quartz-rich rocks of the marine-platformal, lower Cambrian Random Formation (Walcott 1900; Anderson 1981; Hiscott 1982). On Bonavista Peninsula, Musgravetown Group magmatism includes: calc-alkaline basalts of the basal, ca. $600 \mathrm{Ma}$ Cannings Cove Formation; ca. $592 \mathrm{Ma}$ continental tholeiites and alkaline felsic volcanic rocks of the Bull Arm Formation (Plate Cove volcanic belt); >580 Ma alkali (Dam Pond) basalts of the Big Head Formation; minor $<580 \mathrm{Ma}$ alkali basalts at Fifields Pit and Bonaventure Head (Big Head Formation?); and the younger, <580 Ma British Harbour alkali basalts (upper Rocky Harbour Formation). The British Harbour basalts are overlain by terrestrial, sandy to conglomeratic red beds of the Crown Hill Formation. At (a) Bonavista Peninsula

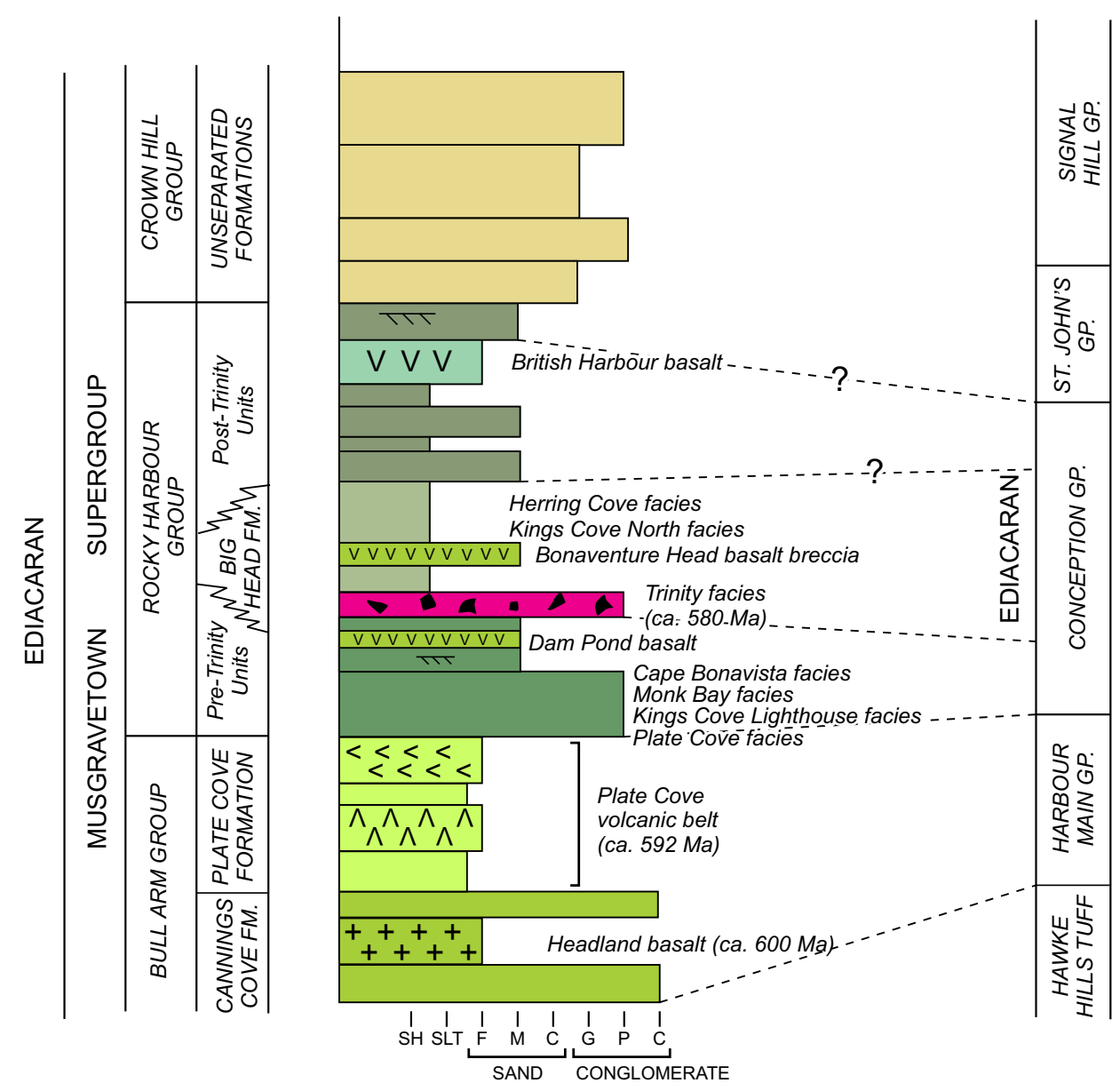

(b) Avalon Peninsula

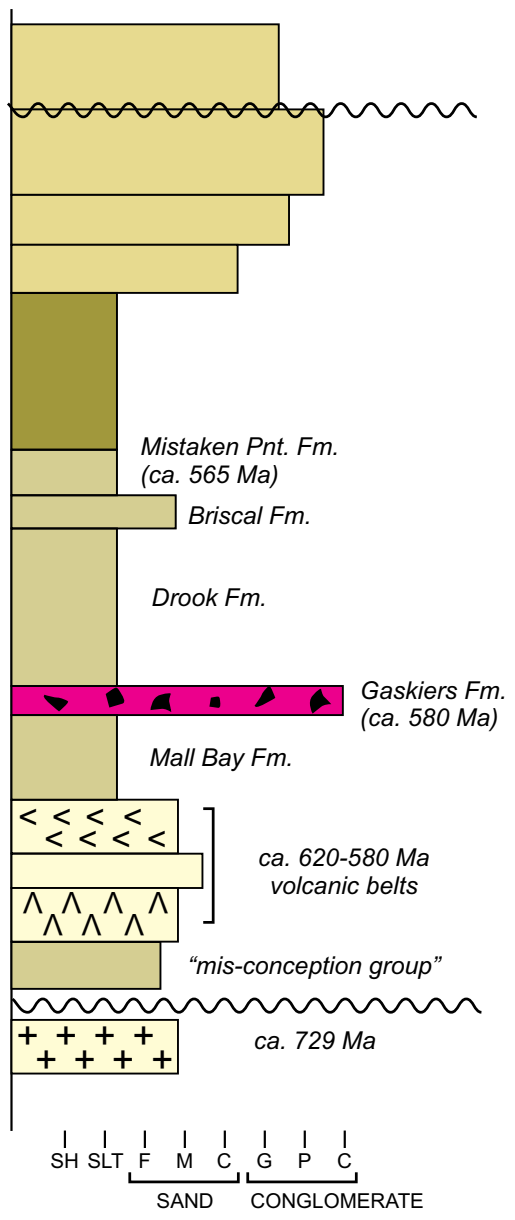

Figure 14. Schematic stratigraphic sections for (a) Bonavista Peninsula and (b) Avalon Peninsula (modified from Myrow 1995), showing geochronological constraints from Skipton et al. (2013) and references therein and Mills et al. (2020) and references therein. 
Keels, northwestern Bonavista Peninsula (Fig. 2), the Crown Hill Formation is disconformably overlain by quartz arenite of the Cambrian Random Formation (Normore 2010). Depending on the erosional depth and/or duration of the depositional hiatus represented by the disconformity at Keels (which may represent a first-order unconformity in the sequence stratigraphic context of Krapez (1996), related to global tectonic cycles; see Fig. 3 for location of Keels), and based on field and geochronological data, the Musgravetown Group, as presently delineated, may include rocks representing an interval of up to 60 m.y., from ca. $600 \mathrm{Ma}$ to an unconstrained age prior to deposition of the Cambrian Random Formation. In contrast, rocks interpreted to span the same interval (from ca. $600 \mathrm{Ma}$ to ca. $540 \mathrm{Ma}$ ) on the Avalon Peninsula comprise four lithostratigraphic units of group-status (Harbour Main, Conception, St. John's and Signal Hill groups). We therefore suggest that the Musgravetown Group be elevated to Supergroup status on the basis of its prolonged depositional interval, the gradual change in geodynamic setting from a subduction-influenced to a less thermally intense extensional regime, as indicated by combined age and lithogeochemical constraints, and because it can be subdivided into volcanic- and sedimentary-dominated units that themselves merit group status.

Units of the lower Musgravetown Supergroup, including the Cannings Cove Formation and Plate Cove volcanic belt (both tentatively placed within the Bull Arm Group; Fig. 14; Table 1), have possible correlative units within the composite, ca. 730-585 Ma Harbour Main Group (see O'Brien et al. 2001). Pre-Trinity facies rocks, including the Plate Cove, Kings Cove Lighthouse, Monk Bay and Cape Bonavista facies, are likely time-correlative with the pre-Gaskiers Mall Bay Formation (Williams and King 1979) and, similarly, post-Trinity facies units (Kings Cove North and Herring Cove facies) are likely correlative with the post-Gaskiers Drook Formation (Fig. 14). Sandstones of the upper Rocky Harbour Formation, or our Rocky Harbour Group, may be similar to those of the Briscal Formation (upper Conception Group; Williams and King 1979). Correlation of the British Harbour volcanics with tuffaceous horizons within the Mistaken Point Formation (see Rettalack 2014; Matthews et al. 2020) remains a possibility that may be tested by geochronological and isotopic studies. Correlation of uppermost Rocky Harbour and Crown Hill groups should await further stratigraphical and geochronological work, and should include units of the Bay de Verde and Cape St. Mary's sub-peninsulas (Fig. 1), including the Maturin Ponds, Heart's Con-tent, Heart's Desire and Trinny Cove formations (King 1988; cf. Hutchinson 1953; McCartney 1967), all of which were previously interpreted to lie stratigraphically above the Big Head Formation and below the Crown Hill Formation, and to be correlative with the mainly alluvial deposits of the Signal Hill Group (King 1988). With further work and a better understanding of the Musgravetown Supergroup, some of its numerous formations may retain their formation status, whereas others may require omission or redefinition as members or groups.

\section{ACKNOWLEDGEMENTS}

Rick Verge of Old Bonaventure provided excellent support as an experienced boatman, and (Jeffrey) David Haynes provided sound field assistance. Chris Finch and staff at the Geochemical Laboratory delivered timely lithogeochemical results. Bruce Ryan, Zsuzsi Magyarosi and John Hinchey provided useful petrographic discussions and insights. Kim Morgan and Terry Sears of the Geological Survey Branch assisted with map preparation and Joanne Rooney prepared the layout and typesetting. The manuscript benefited from critical reviews by Alana Hinchey and David Lowe, and by journal reviewers Brendan Murphy and Chris Hepburn. Chris Pereira provided editorial suggestions on an earlier draft.

\section{REFERENCES}

Anderson, M.M. 1981. The Random Formation of southeastern Newfoundland: a discussion aimed at establishing its age and relationship to bounding formations. American Journal of Science, 281, pp. 807-831. https://doi. org/10.2475/ajs.281.6.807

Benxun, S., Hongfu, Z., Asamoah, S.P., Kezhang, Q., and Yanjie, T. 2013. Garnet-Spinel Transition in the Upper Mantle: Review and Interpretation. Journal of Earth Science 21, pp. 635-640. https://doi.org/10.1007/s12583 -010-0117-x

Brückner, D. and Anderson, M.M. 1971. Late Precambrian glacial deposits in southeastern Newfoundland, a preliminary note. Geological Association of Canada Proceedings, 24, pp. 95-102.

Brückner, D. 1977. Significance of new tillite finds for eastwest correlation of Proterozoic Avalon-zone formations in southeastern Newfoundland (Canada). Estudio Geologico, 33, pp. 357-364.

Cabanis, B. and Lécolle, M. 1989. Le diagramme La/10$\mathrm{Y} / 15-\mathrm{Nb} / 8$ : un outil pour la discrimination des series volcaniques et la mise en evidence des processus de mélange et/ou de contamination crustale. Comptes Rendus de l'Acadamie des Sciences, Series II, 309, pp. 2023-2029.

Christie, A.M. 1950. Geology of Bonavista map-area, Newfoundland (summary account). Department of Mines and Technical Surveys. Geological Survey of Canada. Paper 50-7, 40 p. [002C/0007]. https://doi.org/10.4095/123927

Colman-Sadd, S.P., Hayes, J.P., and Knight, I. 1990. Geology of the Island of Newfoundland (digital version of Map 90-01). Geological Survey Branch, Government of Newfoundland and Labrador, Department of Mines and Energy, Open File GS\# NFLD/2192, scale: 1:1 000000.

Condie, K. 2005. High field strength element ratios in Archean basalts: a window to evolving sources of mantle plumes? Lithos, 79, pp. 491-504. https://doi.org/10.1016/j. lithos.2004.09.014

Finch, C., Roldan, R., Walsh, J.K., and Amor, S. 2018. Analytical methods for chemical analysis of geological 
materials. Geological Survey Branch, Government of Newfoundland and Labrador, Department of Natural Resources, Open File NFLD/3316, 67 p.

Gardiner, S. and Hiscott, R.N. 1988. Deep-water facies and depositional setting of the lower Conception Group (Hadrynian), southern Avalon Peninsula, Newfoundland. Canadian Journal of Earth Sciences, 25, pp. 1579-1594. https://doi.org/10.1139/e88-151

Graves, G. 2003. Noranda Incorporated and Cornerstone Resources Incorporated; First year, first year supplementary, second, third, and fourth year assessment report on geological, geochemical and diamond drilling exploration for license $6363 \mathrm{M}-6364 \mathrm{M}, 7821 \mathrm{M}, 7867 \mathrm{M}-7869 \mathrm{M}$, $7939 \mathrm{M}, \quad 7941 \mathrm{M}-7945 \mathrm{M}, \quad 7948 \mathrm{M}, \quad 8023 \mathrm{M}-8024 \mathrm{M}$, $8069 \mathrm{M}-8099 \mathrm{M}, 8101 \mathrm{M}, 8329 \mathrm{M}, 8457 \mathrm{M}-8468 \mathrm{M}$, and $8810 \mathrm{M}-8812 \mathrm{M}$ on claims in the Duntara to Deer Harbour area, eastern Newfoundland, 2 reports. Noranda Incorporated and Cornerstone Resources Incorporated [NFLD/2832].

Guiseppe, P.D., Agostini, S., Lustrino, M., Karaoglu, Ö., Savaşçin, M.Y., Manetti, P., and Ersoy, Y. 2018. Transition from compression to strike-slip tectonics revealed by Miocene-Pleistocene volcanism west of the Karliova Triple Junction (East Anatolia). Journal of Petrology, 58, pp. 2055-2087. https://doi.org/10.1093/petrology/egx082

Hayes, A.O. 1948. Geology of the area between Bonavista and Trinity bays, eastern Newfoundland. Geological Survey of Newfoundland, Bulletin 32 (Part 1), pp. 1-37.

Hiscott, R.N. 1982. Tidal deposits of the Lower Cambrian Random Formation, eastern Newfoundland: facies and paleoenvironments. Canadian Journal of Earth Sciences, 19, pp. 2028-2042. https://doi.org/10.1139/e82-180

Hofmann, H.J., O’Brien, S.J., and King, A.F. 2008. Ediacaran biota on Bonavista Peninsula, Newfoundland, Canada. Journal of Paleontology, 82 (1), pp. 1-36. https://doi. org/10.1666/06-087.1

Hughes, C.J. and Brückner, W.D. 1971. Late Precambrian rocks of eastern Avalon Peninsula, Newfoundland - A volcanic island complex. Canadian Journal of Earth Sciences, 8, pp. 899-915. https://doi.org/10.1139/e71-081

Hughes, C.J. and Malpas, J.G. 1971. Metasomatism in the late Precambrian Bull Arm Formation in southeastern Newfoundland: recognition and implications, The Geological Association of Canada, Proceedings, 24 (1), pp. 85-93.

Hutchinson, R.D. 1953. Geology of the Harbour Grace map-area, Newfoundland. Geological Survey of Canada Memoir 275, 43 p. https://doi.org/10.4095/123933

Jenness, S.E. 1963. Terra Nova and Bonavista map-areas, Newfoundland (2D E $1 / 2$ and 2C). Geological Survey of Canada, Memoir 327, 184 p. https://doi. org/10.4095/123899

King, A.F. 1988. Geology of the Avalon Peninsula, Newfoundland (parts of $1 \mathrm{~K}, 1 \mathrm{~L}, 1 \mathrm{M}, 1 \mathrm{~N}$ and 2C). Newfoundland Department of Mines and Energy, Map 88 - 01, scale 1:250 000 .

Krapez, K. 1996. Sequence stratigraphic concepts ap- plied to the identification of basin-filling rhythms in Precambrian successions. Australian Journal of Earth Sciences, Volume 43, pp. 355-380. https://doi. org/10.1080/08120099608728260

Large, R.R., Gemmell, J.B., and Paulick, H. 2001. The alteration box plot: A simple approach to understanding the relationship between alteration mineralogy and lithogeochemistry associated with volcanic-hosted massive sulfide deposits. Economic Geology, 96, pp. 957-971. https://doi.org/10.2113/96.5.957

Mason, S.J., Narbonne, G.M., Dalrymple, R.W., and O'Brien, S.J. 2013. Paleoenvironmental analysis of Ediacaran strata in the Catalina Dome, Bonavista Peninsula, Newfoundland. Canadian Journal of Earth Sciences, 50, pp. 197212. https://doi.org/10.1139/cjes-2012-0099

Matton, G. and Jébrak, M. 2009. The Cretaceous Peri-Atlantic Alkaline Pulse (PAAP): Deep mantle plume origin or shallow lithospheric break-up? Tectonophysics, 469, pp. 1-12. https://doi.org/10.1016/j.tecto.2009.01.001

Matthews, J.J., Liu, A.G., Yang, C., McIlroy, D., Levell, B., and Condon, D.J. 2020. A chronostratigraphic framework for the rise of the Ediacaran macrobiota: new constraints from Mistaken Point Ecological Reserve, Newfoundland. Geological Society of America Bulletin, 133 (3-4), pp. 612-624. https://doi.org/10.1130/B35646.1

McCartney, W.D. 1967. Whitbourne map area, Newfoundland. Geological Survey of Canada, Memoir 341, 135 p. https://doi.org/10.4095/123895

Middelburg, J.J., Van der Weijden, C.H., and Woittiez, J.R.W. 1988. Chemical processes affecting the mobility of major, minor and trace elements during weathering of granitic rocks. Chemical Geology, 68, pp. 253-273. https://doi. org/10.1016/0009-2541(88)90025-3

Mills, A.J. 2019. Volcanic arc to arc-rift transition at Cutler Head, Sweet Bay area, Bonavista Peninsula. In Current Research, Newfoundland and Labrador Department of Natural Resources, Geological Survey, Report 19-1, pp. 157-173.

Mills, A.J. 2020. Lithogeochemical database for igneous rocks from the Bonavista Peninsula, northeastern Newfoundland (NTS map area 2C/05, 06, 11 and 12SE). Government of Newfoundland and Labrador, Department of Natural Resources, Geological Survey, Open File 002C/0245, $10 \mathrm{p}$.

Mills, A.J. and Sandeman, H.A.I. 2015. Preliminary lithogeochemistry for mafic volcanic rocks from the Bonavista Peninsula, northeastern Newfoundland. In Current Research, Newfoundland and Labrador Department of Natural Resources, Geological Survey, Report 15-1, pp. 173-189.

Mills, A.J. and Sandeman, H.A.I. 2017. Lithogeochemistry of mafic intrusive rocks from the Bonavista Peninsula, Avalon Terrane, northeastern Newfoundland. In Current Research, Newfoundland and Labrador Department of Natural Resources, Geological Survey, Report 15-1, pp. 173-189.

Mills, A.J. and Sandeman, H.A.I. 2021. Reconnaissance 
lithogeochemical investigation of the Bull Arm Formation and significance of diamictite in the overlying Big Head Formation in the Long Harbour - Placentia area, western Avalon Peninsula, Newfoundland. In Current Research, Newfoundland and Labrador Department of Industry, Energy and Technology, Geological Survey, Report 21-1, pp. 73-91.

Mills, A.J., Calon, T., and Peddle, C. 2016a. Preliminary investigations into the structural geology of the Bonavista Peninsula, northeast Newfoundland. In Current Research, Newfoundland and Labrador Department of Natural Resources, Geological Survey, Report 16-1, pp. 133-152.

Mills, A.J., Dunning, G.R., and Langille, A. 2016b. New geochronological constraints on the Connecting Point Group, Bonavista Peninsula, Avalon Zone, Newfoundland. In Current Research, Newfoundland and Labrador Department of Natural Resources, Geological Survey, Report 16-1, pp. 153-171.

Mills, A.J., Dunning, G.R., Murphy, M., and Langille, A. 2017. New geochronological constraints on the timing of magmatism for the Bull Arm Formation, Musgravetown Group, Avalon Terrane, Newfoundland. In Current Research, Newfoundland and Labrador Department of Natural Resources, Geological Survey, Report 17-1, pp. 1-17.

Mills, A.J. and Dunning, G., and Sandeman, H. 2020. Lithogeochemical, isotopic, and $\mathrm{U}-\mathrm{Pb}$ (zircon) age constraintson arc to rift magmatism, northwestern and central AvalonTerrane, Newfoundland, Canada: implications for local lithostratigraphy. Canadian Journal of Earth Sciences. https://doi.org/10.1139/cjes-2019-0196

Myrow, P.M. 1995. Neoproterozoic rocks of the Newfoundland Avalon Zone. Precambrian Research, 73, pp. 123136. https://doi.org/10.1016/0301-9268(94)00074-2

Niu, Y. Wilson, M., Humphreys, E.R., and O'Hara, M.J. 2011. The origin of intra-plate ocean island basalts (OIB): the Lid Effect and its geodynamic implications. Journal of Petrology, 52, pp. 1443-1468. https://doi.org/10.1093/ petrology/egr030

Normore, L.S. 2010. Geology of the Bonavista map area (NTS 2C/11), Newfoundland. In Current Research, Newfoundland and Labrador Department of Natural Resources, Geological Survey, Report 10-1, pp. 281-301.

Normore, L.S. 2011. Preliminary findings on the geology of the Trinity map area (NTS 2C/06), Newfoundland. In Current Research, Newfoundland and Labrador Department of Natural Resources, Geological Survey, Report 111, pp. 273-293.

Normore, L.S. 2012a. Geology of the Random Island map area (NTS 2C/04), Newfoundland. In Current Research, Newfoundland and Labrador Department of Natural Resources, Geological Survey, Report 12-1, pp. 121-145.

Normore, L.S. 2012b. Geology of the Random Island map area (NTS 2C/04), Newfoundland. Government of Newfoundland Labrador, Department of Natural Resources, Geological Survey. Map 2012-06, scale 1:50 000. GS\#002C/04/0191

O'Brien, S.J. and King, A.F. 2002. Neoproterozoic stratigra- phy of the Bonavista Peninsula: preliminary results, regional correlations and implications for sediment-hosted stratiform copper exploration in the Newfoundland Avalon Zone. In Current Research, Newfoundland Department of Mines and Energy Geological Survey, Report 02-1, pp. 229-244.

O'Brien, S.J. and King, A.F. 2004. Late Neoproterozoic to earliest Paleozoic stratigraphy of the Avalon Zone in the Bonavista Peninsula, Newfoundland: an update. In Current Research, Newfoundland Department of Mines and Energy Geological Survey, Report 04-1, pp. 213-224.

O'Brien, S.J. and King, A.F. 2005. Late Neoproterozoic (Ediacaran) stratigraphy of the Avalon Zone sedimentary rocks, Bonavista Peninsula, Newfoundland. In Current Research. Newfoundland and Labrador Department of Natural Resources, Geological Survey, Report 05-1, pp. 101-114 [NFLD/2903].

O’Brien, S.J., Dubé, B., O'Driscoll, C.F., and Mills, J. 1998. Geological setting of gold mineralization and related hydrothermal alteration in late Neoproterozoic (post-640 Ma) Avalonian rocks of Newfoundland, with a review of coeval gold deposits elsewhere in the Appalachian Avalonian belt. In Current Research. Newfoundland and Labrador Department of Natural Resources, Geological Survey, Report 98-1, pp. 93-124.

O’Brien, S.J., Dubé, B., and O'Driscoll, C.F. 1999. High-sulphidation, epithermal-style hydrothermal systems in late Neoproterozoic Avalonian rocks on the Burin Peninsula, Newfoundland: implications for gold exploration. In Current Research. Newfoundland and Labrador Department of Natural Resources, Geological Survey, Report 99-1, pp. 275-296.

O'Brien, S.J., O’Brien, B.H., Dunning, G.R., and Tucker, R.D. 1996. Late Neoproterozoic Avalonian and related peri-Gondwanan rocks of the Newfoundland Appalachians. In Avalonian and Related Peri-Gondwanan Terranes of the Circum-North Atlantic. Edited by R.D. Nance, R.D. and M.D. Thompson. Geological Society of America Special Paper, 304, pp. 9-27. https://doi.org/10.1130/08137-2304-3.9

O’Brien, S.J., Dunning, G.R., Dubé, C.F, Sparkes, B., Israel, S., and Ketchum, J. 2001. New insights into the Neoproterozoic geology of the central Avalon Peninsula (parts of NTS map areas $1 \mathrm{~N} / 6,1 \mathrm{~N} / 7$ and $1 \mathrm{~N} / 3$ ), Eastern Newfoundland. In Current Research, Newfoundland Department of Mines and Energy Geological Survey, Report 2001-1, pp 169-189.

Pearce, J.A. 1996. A user's guide to basalt discrimination diagrams. In Trace Element Geochemistry of Volcanic Rocks; Applications for Massive Sulphide Exploration. Short Course Notes, Geological Association of Canada, 12, pp. 79-113.

Pearce, J.A. 2008. Geochemical fingerprinting of oceanic basalts with applications to ophiolite classification and the search for Archean oceanic crust. Lithos, 100, pp. 14-48. https://doi.org/10.1016/j.lithos.2007.06.016

Pearce, J.A. and Cann, J.R. 1973. Tectonic setting of basic 
volcanic rocks determined using trace element analyses. Earth and Planetary Science Letters, 19, pp. 290-300. https://doi.org/10.1016/0012-821X(73)90129-5

Pearce, J.A. and Norry, M.J. 1979. Petrogenetic implications of $\mathrm{Ti}, \mathrm{Zr}, \mathrm{Y}$, and $\mathrm{Nb}$ variations in volcanic rocks. Contributions to Mineralogy and Petrology, 69, pp. 33-47. https://doi.org/10.1007/BF00375192

Piercey, S.J., Nelson, J.L., Colpron, M., Dusel-Bacon, C., Simard, R.-L., and Roots, C.F. 2006. Paleozoic magmatism and crustal recycling along the ancient Pacific margin of North America, northern Cordillera. In Paleozoic Evolution and Metallogeny of Pericratonic Terranes at the Ancient Pacific Margin of North America, Canadian and Alaskan Cordillera. Edited by M. Colpron, M. and J.L. Nelson. Geological Association of Canada, Special Paper, 45, pp. 281-322.

Pu, J.P., Bowring, S.A., Ramezani, J., Myrow, P., Raub, T.D., Landing, E., Mills, A., Hodgin, E., and Macdonald, F.A. 2016. Dodging snowballs: Geochronology of the Gaskiers glaciation and the first appearance of the Ediacaran biota. Geology, 44, pp. 955-958. https://doi.org/10.1130/G38284.1

Retallack, G.J. 2014. Volcanosedimentary paleoenvironments of Ediacaran fossils in Newfoundland. Geological Society of America Bulletin, 126, pp. 619-638. https:// doi.org/10.1130/B30892.1

Rock, N.M.S. 1991. Lamprophyres. Van Nostrand Reinhold, New York, 285 p. https://doi.org/10.1007/978-1-47570929-2

Rooney, T.O. 2010. Geochemical evidence of lithospheric thinning in the southern Main Ethiopian Rift. Lithos, 117, pp. 33-48. https://doi.org/10.1016/j.lithos.2010.02.002

Rudnick, R.L. and Gao, S. 2003. Composition of the continental crust. Treatise on geochemistry, 3, 659 p. https:// doi.org/10.1016/B0-08-043751-6/03016-4

Skipton, D.R., Dunning, G.R., and Sparkes, G.W. 2013. Late Neoproterozoic arc-related magmatism in the Horse Cove Complex, eastern Avalon Zone, Newfoundland. Canadian Journal of Earth Sciences, 50, pp. 462-482. https://doi. org/10.1139/cjes-2012-0090

Sparkes, G.W. and Dunning, G.R. 2014. Late Neoproterozoic epithermal alteration and mineralization in the western Avalon Zone: a summary of mineralogical investigations and new $\mathrm{U} / \mathrm{Pb}$ geochronological results. In Current Re- search, Newfoundland and Labrador Department of Natural Resources, Geological Survey, Report 14-1, pp. 99-128.

Sun, S.S. and McDonough, W.F. 1989. Chemical and isotopic systematics of oceanic basalts: implications for mantle composition and processes. In Magmatism in the Ocean Basin. Edited by A.D. Saunders and M.J. Norry. Geological Society of London, Special Publication 42, pp. 313345. https://doi.org/10.1144/GSL.SP.1989.042.01.19

van Staal, C.R., Winchester, J.A., and Bédard, J.H. 1991. Geochemical variations in Middle Ordovician volcanic rocks of the northern Miramachi Highlands and their tectonic significance. Canadian Journal of Earth Sciences, 28, pp. 1031-1049. https://doi.org/10.1139/e91-094

Walcott, C.D. 1900. Random, a pre-Cambrian Upper Algonkian Terrane. Bulletin Geological Society of America, 11, pp. 3-5.

Wass, S. 1973. The origin and petrogenetic significance of hour-glass zoning in titaniferous clinopyroxenes. Mineralogical Magazine, 39 (302), pp. 33-44. https://doi. org/10.1180/minmag.1973.039.302.01

Williams, H. and King, A.F. 1979. Trepassey map area, Newfoundland. Geological Survey, Memoir 389, pp. 1-24. https://doi.org/10.4095/124185

Wood, D.A. 1980. The application of a Th-Hf-Ta diagram to problems of tectomagmatic classification and to establishing the nature of crustal contamination of basaltic lavas of the British Tertiary Volcanic Province. Earth and Planetary Science Letters, 50, pp. 11-30. https://doi. org/10.1016/0012-821X(80)90116-8

Youbi, N., Ernst, R.E., Söderlund, U., Boumehdi, M.A., Air Lahna, A., Tassinari, C.C.G., El Moume, W., and Bensalah, M.K. 2020. The Central Iapetus magmatic province: An updated review and link with the ca. $580 \mathrm{Ma}$ Gaskiers glaciation. In Mass extinctions, volcanism, and impacts: new developments. Edited by T. Adatte, D.P.G. Bond, and G. Keller. Geological Society of America Special Paper, 544, pp. 35-66. https://doi.org/10.1130/2020.2544(02)

Ziberna, L., Klemme, S., and Nimis, P. 2013. Garnet and spinel in fertile and depleted mantle: insights from thermodynamic modelling. Contributions to Mineralogy and Petrology, 166, pp. 411-421. https://doi.org/10.1007/ s00410-013-0882-5

Editorial responsibility: Sandra M. Barr 
Appendix. Lithogeochemical data for alkaline rocks of the Bonavista Peninsula area. Note: $-99=$ not analyzed; reported negative values indicate that the analysis was below the quoted detection limit; ${ }^{*}$ UTM Datum NAD27.Unit/Cuts refers to either the rock unit or the unit a dyke crosscuts; Fi-Pit = Fifields Pit; Bon-Head = Bonaventure Head; $\mathrm{BrHr}$-vlc $=$ British Harbour volcanic rock; $\mathrm{BrHr}-\mathrm{pyr}=$ British Harbour pyroclastic rock.

\begin{tabular}{|c|c|c|c|c|c|c|c|c|c|c|}
\hline Sample & 14AM143A & 14AM111C & 14AM111C01 & 19AM021C & $14 \mathrm{AM} 286 \mathrm{~A} 0$ & 14AM287B & $14 \mathrm{AM} 299 \mathrm{C} 0$ & 17AM089 & 19AM022B & 14AM284A0 \\
\hline UTMEast $^{\star}$ & 326028 & 320658 & 320658 & 765765.88 & 314727 & 314911 & 318364 & 315348 & 760111.75 & 760111.75 \\
\hline UTMNorth* & 5364918 & 5350048 & 5350048 & 5353394.6 & 5346683 & 5346895 & 5350706 & 5352755 & 5349669.9 & 5349669.86 \\
\hline $\begin{array}{l}\text { UTMZone } \\
\text { Rock-Type } \\
\text { Unit/Cuts }\end{array}$ & $\begin{array}{c}22 \\
\text { mafic } \\
\text { fragmental/ } \\
\text { Fi-Pit }\end{array}$ & $\begin{array}{c}22 \\
\text { mafic } \\
\text { fragmental/ } \\
\text { Bon-Head }\end{array}$ & $\begin{array}{c}22 \\
\text { mafic } \\
\text { fragmental/ } \\
\text { Bon-Head }\end{array}$ & $\begin{array}{c}21 \\
\text { mafic } \\
\text { fragmental/ } \\
\text { Bon-Head }\end{array}$ & $\begin{array}{c}22 \\
\text { basaltic } \\
\text { dyke } \\
\text { BrHr-vlc }\end{array}$ & $\begin{array}{c}22 \\
\text { basaltic } \\
\text { dyke } \\
\text { BrHr-vlc }\end{array}$ & $\begin{array}{c}22 \\
\text { carbonatized } \\
\text { gabbro dyke } \\
\text { BrHr-vlc }\end{array}$ & $\begin{array}{c}22 \\
\text { gabbro } \\
\text { dyke } \\
\text { BrHr-vlc }\end{array}$ & $\begin{array}{c}21 \\
\text { columnar- } \\
\text { jointed } \\
\text { BrHr-vlc }\end{array}$ & $\begin{array}{c}21 \\
\text { massive } \\
\text { basalt } \\
\text { BrHr-vlc }\end{array}$ \\
\hline $\mathrm{SiO}_{2}$ & 45.6 & 48.14 & 48.4 & 47.35 & 48.15 & 59.2 & 44.6 & 51.84 & 47.91 & 45.36 \\
\hline $\mathrm{Fe}_{2} \mathrm{O}_{3}{ }^{\mathrm{T}}$ & 9.96 & 9.74 & 9.5 & 9.87 & 13.45 & 7.19 & 14.5 & 14 & 13.11 & 13.13 \\
\hline $\mathrm{Fe}_{2} \mathrm{O}_{3}$ & 3.21 & 2.8 & 3.07 & 3.09 & 3.96 & 1.6 & 3.07 & 12.05 & 4.8 & 2.71 \\
\hline $\mathrm{FeO}$ & 6.08 & 6.25 & 5.79 & 6.11 & 8.54 & 5.03 & 10.29 & 1.75 & 7.48 & 9.38 \\
\hline $\mathrm{FeO}^{\mathrm{T}}$ & 8.97 & 8.76 & 8.55 & 8.88 & 12.1 & 6.47 & 13.05 & 12.6 & 11.8 & 11.82 \\
\hline $\mathrm{MgO}$ & 10.65 & 9.16 & 8.28 & 8.56 & 4.4 & 1.39 & 2.83 & 1.99 & 3.75 & 4.08 \\
\hline $\mathrm{CaO}$ & 8.17 & 6.2 & 5.85 & 7.69 & 6.47 & 1.25 & 7.06 & 4.03 & 6.42 & 6.38 \\
\hline LOI & 4.89 & 4.95 & 4 & 4.24 & 2.59 & 1.74 & 6.49 & 1.44 & 2.28 & 4.4 \\
\hline Total & 98.09 & 100.61 & 98.71 & 99.2 & 100.37 & 99.85 & 100.06 & 100.04 & 98.83 & 100.27 \\
\hline $\mathrm{Mg} \#$ & 67.93 & 65.06 & 63.32 & 49.08 & 39.34 & 27.67 & 27.89 & 21.93 & 36.16 & 38.1 \\
\hline $\mathrm{Cr}$ & 825 & 535 & 487 & 395 & -1 & 1 & 2 & 6 & 2 & 1 \\
\hline $\mathrm{Zr}$ & 110 & 220 & 198 & 186 & 397 & 949 & 344 & 253 & 391 & 489 \\
\hline $\mathrm{Ba}$ & 115 & 184 & 110 & 122 & 655 & 29 & 151 & 153 & 688 & 693 \\
\hline $\mathrm{V}$ & 311 & 236 & 246 & 244 & 135 & -5 & 128 & 231 & 131 & 113 \\
\hline Co & 40 & 48 & 41 & 52 & 21 & 2 & 28 & 41 & 23 & 20 \\
\hline Ga & 16 & 27 & 23 & 25 & 24 & 39 & 27 & 14 & 25 & 32 \\
\hline $\mathrm{Ge}$ & 4 & 8 & 6 & 3 & 6 & 7 & 6 & -1 & 2 & 6 \\
\hline $\mathrm{Sr}$ & 123 & 266 & 245 & 372 & 299 & 107 & 291 & 348 & 325 & 371 \\
\hline $\mathrm{Y}$ & 21 & 27 & 21 & 22 & 55 & 82 & 54 & 37 & 52 & 69 \\
\hline $\mathrm{Tb}$ & 0.7 & 1.2 & 1 & 1 & 2 & 2.6 & 2 & 1.5 & 2 & 2.5 \\
\hline $\mathrm{Gd}$ & 4.6 & 9.1 & 7.1 & 8.1 & 13.5 & 16.6 & 13.8 & 9.8 & 13.3 & 17 \\
\hline Dy & 4 & 5.9 & 4.8 & 5.1 & 11.4 & 15.5 & 11.2 & 8.4 & 11.1 & 14.3 \\
\hline Ho & 0.8 & 1 & 0.8 & 0.9 & 2.2 & 3.1 & 2.1 & 1.6 & 2 & 2.7 \\
\hline Er & 2.3 & 2.9 & 2.3 & 2.3 & 6.1 & 9.4 & 5.8 & 4.5 & 5.8 & 7.5 \\
\hline $\mathrm{Tm}$ & 0.28 & 0.33 & 0.27 & 0.31 & 0.79 & 1.35 & 0.74 & 0.55 & 0.79 & 1 \\
\hline $\mathrm{Yb}$ & 1.9 & 2.1 & 1.8 & 1.9 & 5.1 & 9.5 & 4.8 & 3.6 & 5 & 6.6 \\
\hline $\mathrm{Lu}$ & 0.3 & 0.29 & 0.27 & 0.27 & 0.76 & 1.36 & 0.71 & 0.56 & 0.74 & 0.93 \\
\hline $\mathrm{Hf}$ & 2.9 & 4.9 & 4.4 & 4.3 & 9.6 & 21.4 & 8 & 6.3 & 9.2 & 11.6 \\
\hline $\mathrm{Ta}$ & 2.5 & 3.3 & 3 & 2.1 & 3.3 & 6.5 & 3.2 & 1.8 & 2.6 & 3.7 \\
\hline Th & 3.5 & 7.8 & 7.5 & 6.8 & 3.6 & 9 & 3.4 & 4.3 & 3.2 & 4.3 \\
\hline $\mathrm{U}$ & 0.81 & 2.24 & 2.1 & 1.9 & 1.14 & 2.76 & 1.05 & 1.97 & 1 & 1.35 \\
\hline $\mathrm{Be}$ & 1 & 2.4 & 2.6 & -99 & 2.6 & 2.4 & 1.1 & -99 & -99 & 3.2 \\
\hline $\mathrm{Cu}$ & 66 & 47 & 42 & 74 & 12 & 4 & 13 & 17 & 8 & 17 \\
\hline $\mathrm{Fe}$ & -99 & -99 & -99 & -99 & -99 & -99 & -99 & -99 & -99 & -99 \\
\hline $\mathrm{Li}$ & 78.2 & 103.6 & 99.5 & 81.6 & 36.8 & 28.7 & 94.9 & 24.6 & 28.5 & 31.7 \\
\hline $\mathrm{Mn}$ & 1647 & 1801 & 1690 & -99 & 2096 & 1764 & 2672 & -99 & -99 & 2717 \\
\hline $\mathrm{Ni}$ & 223 & 219 & 207 & 207 & 13 & 8 & 13 & 21 & 13 & 12 \\
\hline $\mathrm{Rb}$ & 14 & 7 & 8 & 8 & 39 & 7 & 22 & 12 & 36 & 23 \\
\hline $\mathrm{Sc}$ & 38.9 & 30.3 & 26.8 & -99 & 24.5 & 15.5 & 20 & -99 & -99 & 21.7 \\
\hline $\mathrm{Ti}$ & 9798 & 12526 & 11499 & 9970 & 18959 & 3961 & 6614 & 21339 & 18195 & 16461 \\
\hline $\mathrm{Zn}$ & 73 & 80 & 78 & 71 & 139 & 183 & 154 & 125 & 131 & 160 \\
\hline $\mathrm{F}$ & 478 & 930 & 945 & 1054 & 733 & 253 & 901 & 253 & 568 & 1087 \\
\hline
\end{tabular}


Appendix. Continued.

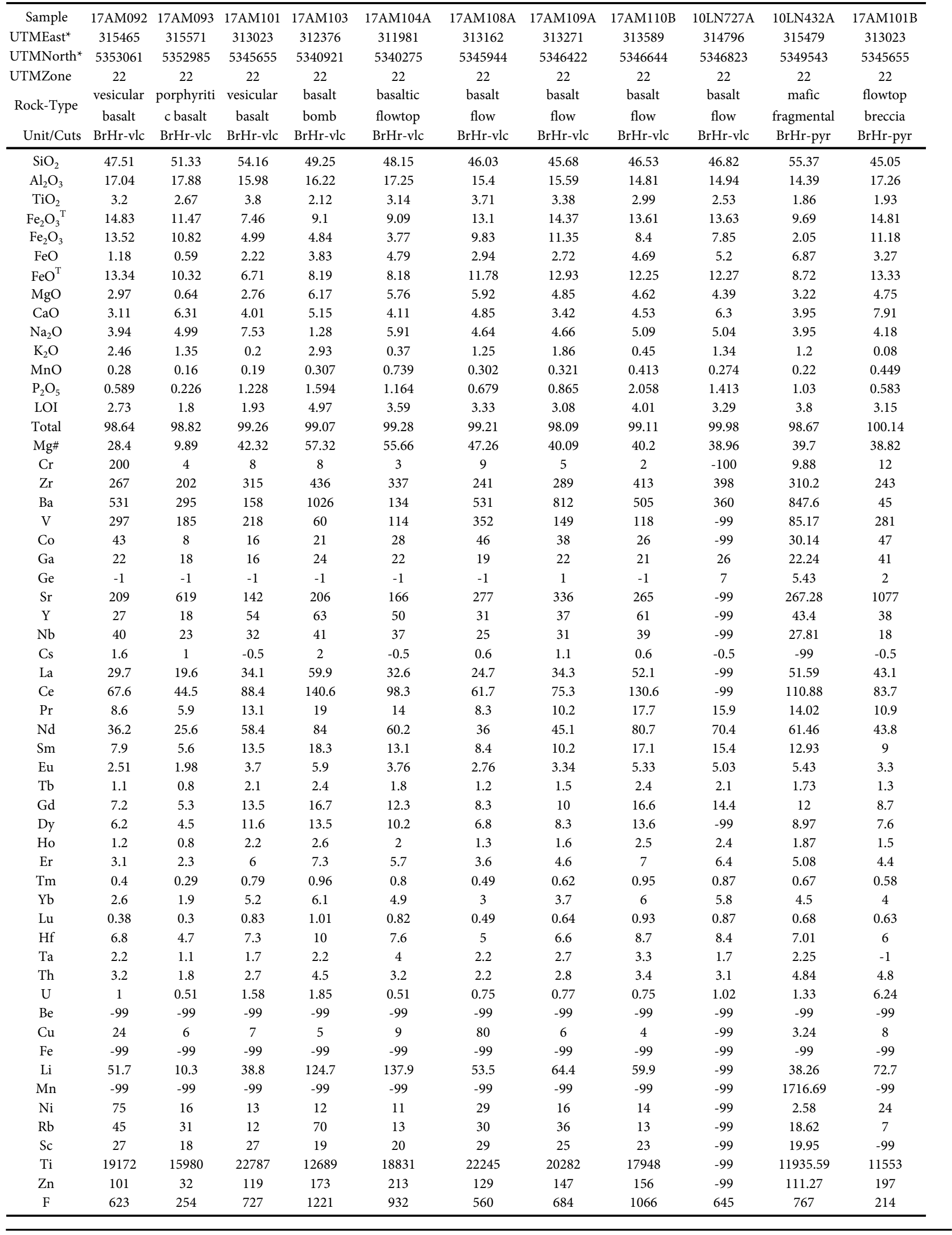


Appendix. Continued.

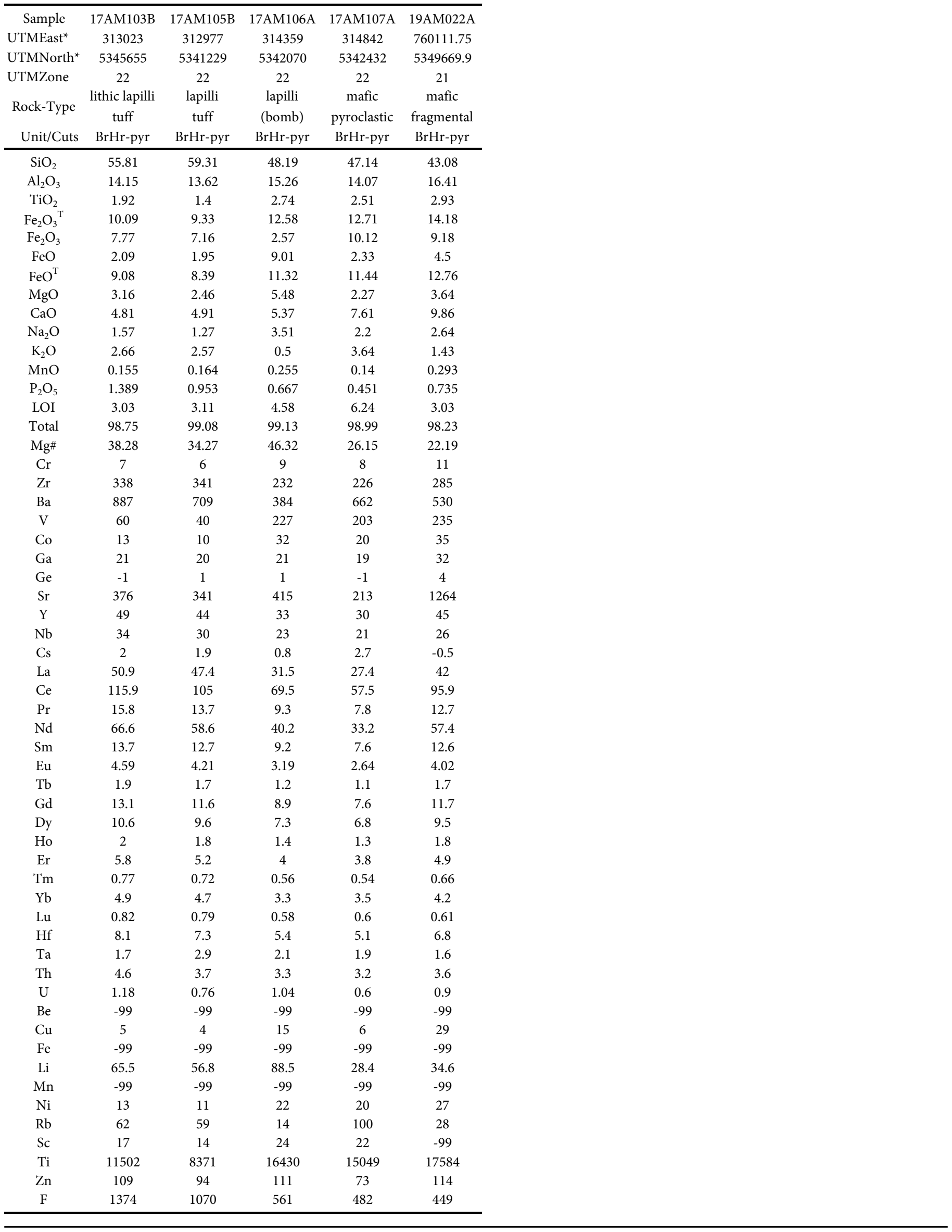

